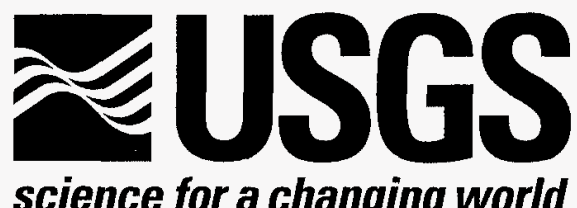

30

\title{
ANALYSIS OF A MULTIPLE-WELL INTERFERENCE TEST IN MIOCENE TUFFACEOUS ROCKS AT THE C-HOLE COMPLEX, MAY-JUNE 1995, YUCCA MOUNTAIN, NYE COUNTY, NEVADA
}

U.S. GEOLOGICAL SURVEY USGS/WRIR--97-4/66

Water-Resources Investigations Report 97-4166

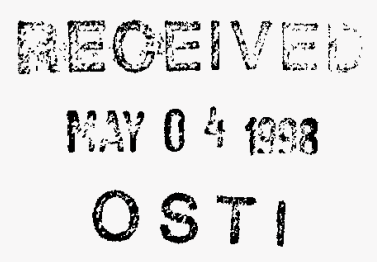

DTIC QUALTTY INOPECTED I

Prepared in cooperation with the NEVADA OPERATIONS OFFICE, U.S. DEPARTMENT OF ENERGY, under Interagency Agreement DE-AI08-92NV10874

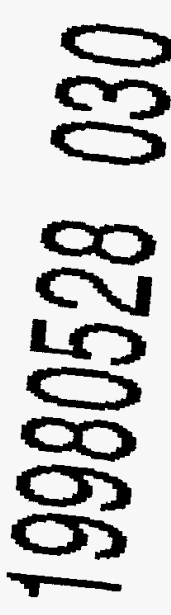




\section{DISCLAIMER}

This report was prepared as an account of work sponsored by an agency of the United States Government. Neither the United States Government nor any agency thereof, nor any of their employees, makes any warranty, express or implied, or assumes any legal liability or responsibility for the accuracy, completeness, or usefulness of any information, apparatus, product, or process disclosed, or represents that its use would not infringe privately owned rights. Reference herein to any specific commercial product, process, or service by trade name, trademark, manufacturer, or otherwise does not necessarily constitute or imply its endorsement, recommendation, or favoring by the United States Government or any agency thereof. The views and opinions of authors expressed herein do not necessarily state or reflect those of the United States Government or any agency thereof. 


\section{ANALYSIS OF A MULTIPLE-WELL INTERFERENCE TEST IN MIOCENE TUFFACEOUS ROCKS AT THE C-HOLE COMPLEX, MAY-JUNE 1995, YUCCA MOUNTAIN, NYE COUNTY, NEVADA}

by Arthur L. Geldon, Amjad M.A. Umari, John D. Earle, Michael F. Fahy, James M. Gemmell, and Jon Darnell

$$
\text { USGS/WRIR - -97-4166 }
$$

U.S. GEOLOGICAL SURVEY

Water-Resources Investigations Report 97-4166

Prepared in cooperation with the

NEVADA OPERATIONS OFFICE,

U.S. DEPARTMENT OF ENERGY, under

Interagency Agreement DE-Al08-92NV10874

DISTRIBUTION OF THIS DOCUMENT Is UNLIMITED

Denver, Colorado

1998 


\title{
U.S. DEPARTMENT OF THE INTERIOR \\ BRUCE BABBITT, Secretary
}

\author{
U.S. GEOLOGICAL SURVEY
}

Thomas J. Casadevall, Acting Director

The use of firm, trade, and brand names in this report is for identification purposes only and does not constitute endorsement by the U.S. Geological Survey.

For additional information write to:

Chief, Earth Science Investigations Program

Yucca Mountain Project Branch

U.S. Geological Survey

Box 25046, Mail Stop 421

Denver Federal Center

Denver, CO 80225-0046
Copies of this report can be purchased from:

U.S. Geological Survey

Information Services

Box 25286

Federal Center

Denver, CO 80225 


\section{CONTENTS}

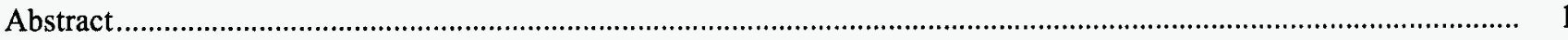

Introduction

Purpose and Scope

Previous Work

Methods

Acknowledgments

Physical Setting

Pumping Test Description

Monitoring Network

Atmospheric Pressure, Earth Tides, and Barometric Efficiency

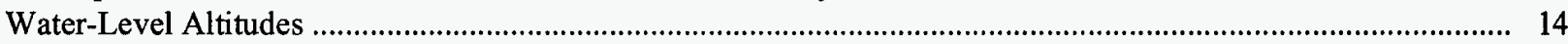

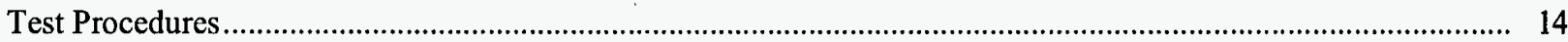

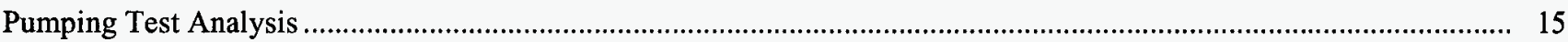

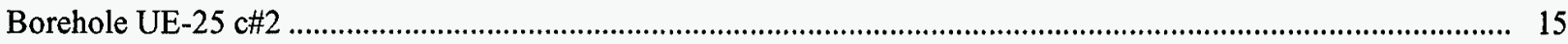

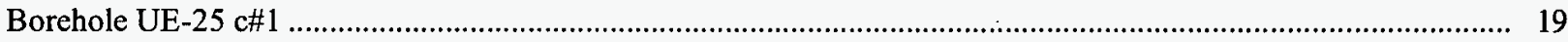

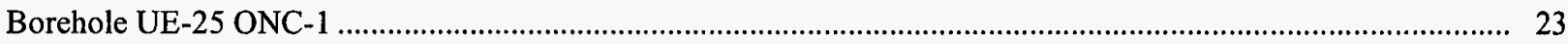

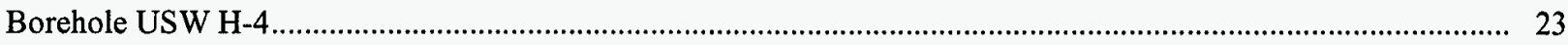

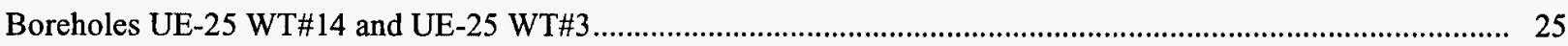

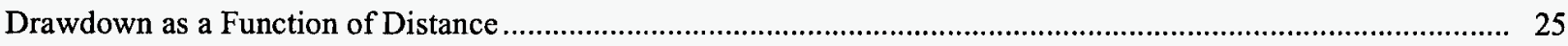

Comparison Between 1984 and 1995 Aquifer-Test Results.................................................................................. 29

Hydraulic Connection Between Miocene and Paleozoic Rocks................................................................................... 30

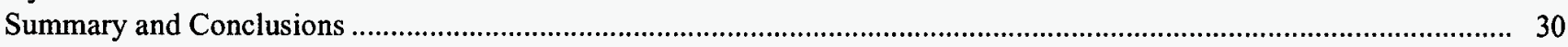

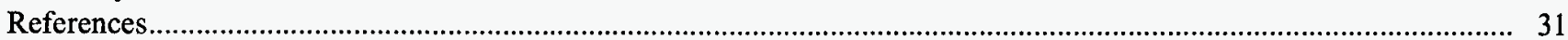

FIGURES

1. Map showing location of the C-hole complex, boreholes UE-25 c\#1, UE-25 c\#2, and UE-25 c\#3 ...................... 3

2. Generalized geologic map showing location of the C-hole complex and nearby boreholes ................................... 5

3. Hydrogeologic section from Boundary Ridge to Fran Ridge ......................................................................... 7

4. Map showing potentiometric surface of the Miocene tuffaceous rocks in the vicinity of the C-hole complex, May 1995

5. Hydrogeologic section showing hydrogeologic intervals in the C-holes, May 1995 to August 1996 .................... 9

6-12. Graphs showing:

6. Atmospheric pressure at the C-hole complex and at borehole UE-25 ONC-1, May-June 1995 ..................... 12

7. Determination of barometric efficiency in boreholes UE- $25 \mathrm{c} \# 1$ and UE-25 $\mathrm{c} \# 3$ from changes in water-level altitude and atmospheric pressure July 15-September 8, 1993 ................................................. 13

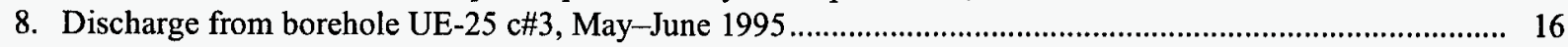

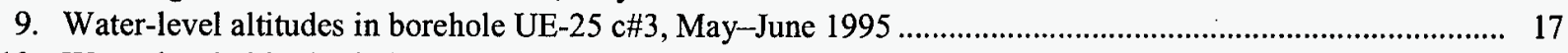

10. Water-level altitudes in boreholes UE-25 c\#1, UE-25 c\#2, and USW H-4, May-June 1995 ............................ 17

11. Water-level altitudes in boreholes UE-25 ONC-1, UE-25 WT\#3, and UE-25 WT\#14, May-June 1995

12. Water-level altitudes in borehole UE-25 p\#1, May-June 1995 ............................................................ 18

13. Map showing drawdown in the vicinity of borehole UE-25 c\#3, 14,000 minutes after pumping started,

May-June 1995

14-21. Graphs showing:

14. Analysis of drawdown in borehole UE-25 c\#2, May-June 1995........................................................ 20

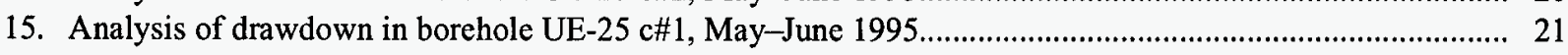

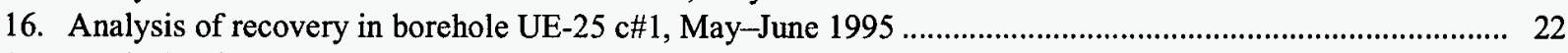

17. Analysis of drawdown in borehole UE-25 ONC-1, May-June 1995 ................................................. 24

18. Analysis of drawdown in borehole USW H-4, May-June 1995 ............................................................ 26 
19. Residual changes in water-level altitudes in boreholes UE-25 WT\#14 and UE-25 WT\#3 after applying corrections for Earth-tide and barometric effects, May-June 1995.

20. Analysis of drawdown in observation wells as a function of distance from the pumping well after 14,000 minutes of pumping, May-June 1995 .

21. Residual changes in water-level altitudes in borehole UE-25 p\#1 after applying corrections for Earth-tide and barometric effects, May-June 1995

\section{TABLES}

1. Stratigraphy of Miocene tuffaceous rocks in the C-hole area .

2. Barometric efficiency values determined for boreholes monitored during the pumping test in borehole UE-25 c\#3, May-June 1995

3. Initial water-level altitudes in boreholes monitored during the pumping test in borehole UE-25 $\mathrm{c} \#$,

May-June 1995.

4. Summary of hydrologic properties computed from drawdown or recovery with time in observation wells, pumping test in borehole UE-25 c\#3, May-June 1995

5. Summary of hydrologic properties determined from aquifer tests at the C-hole complex in 1984 and 1995.

\section{CONVERSION FACTORS, VERTICAL DATUM, AND ABBREVIATIONS}

\begin{tabular}{rcl}
\hline Multiply & By & To obtain \\
\hline cubic meter per day $\left(\mathrm{m}^{3} / \mathrm{d}\right)$ & 35.31 & cubic foot per day \\
centimeter $(\mathrm{cm})$ & 0.3937 & inch \\
kilometer $(\mathrm{km})$ & 0.6214 & mile \\
kilopascal $(\mathrm{kPa})$ & 0.1450 & pound per square inch \\
liter $(\mathrm{L})$ & 0.2642 & gallon \\
liter per second $\mathrm{m}(\mathrm{L} / \mathrm{s})$ & 15.85 & gallon per minute \\
meter $(\mathrm{m})$ & 3.2808 & foot \\
meter per day $(\mathrm{m} / \mathrm{d})$ & 3.2808 & foot per day \\
meter squared per day $\left(\mathrm{m}^{2} / \mathrm{d}\right)$ & 10.76 & foot squared per day \\
square $\mathrm{meter}$ & 10.76 & square foot \\
\hline
\end{tabular}

Temperature in degrees Celsius $\left({ }^{\circ} \mathrm{C}\right)$ may be converted to degrees Fahrenheit $\left({ }^{\circ} \mathrm{F}\right)$ as follows:

$$
{ }^{\circ} \mathrm{F}=\left(1.8 \times{ }^{\circ} \mathrm{C}\right)+32
$$

Sea level: In this report, "sea level" refers to the National Geodetic Vertical Datum of 1929 (NGVD of 1929) - a geodetic datum derived from a general adjustment of the first-order level nets of both the United States and Canada, formerly called Sea Level Datum of 1929. 


\title{
Analysis of a Multiple-Well Interference Test in Miocene Tuffaceous Rocks at the C-Hole Complex, May-June 1995, Yucca Mountain, Nye County, Nevada
}

\author{
By Arthur L. Geldon, Amjad M.A. Umari, John D. Earle, Michael F. Fahy, James M. Gemmell, \\ and Jon Darnell
}

\section{ABSTRACT}

A multiple-well interference (pumping) test was conducted in Miocene tuffaceous rocks at the C-hole complex at Yucca Mountain, Nev., from May 22 to June 12, 1995, by the U.S. Geological Survey, in cooperation with the U.S. Department of Energy. This pumping test was conducted as part of investigations to determine the suitability of Yucca Mountain as a potential site for the storage of high-level nuclear waste in a mined geologic repository. During the test, borehole UE-25 $\mathrm{c} \# 3$ was pumped for 10 days at an average rate of 17.9 liters per second. Drawdown in 6 observation wells completed in Miocene tuffaceous rocks $29.0-3,525.6$ meters from the pumping well ranged from 0 to 0.42 meters 14,000 minutes after pumping started. The spatial distribution of this drawdown indicates that a northwest-trending zone of discontinuous faults might be affecting ground-water movement in the Miocene tuffaceous rocks near the C-holes. No drawdown was observed in a borehole completed in a regional Paleozoic carbonate aquifer 630.0 meters from the pumping well. Consequently, it could not be determined during the pumping test if the Miocene tuffaceous rocks are connected hydraulically to the regional aquifer. Analyses of drawdown and recovery indicate that the Miocene tuffaceous rocks in the vicinity of the $\mathrm{C}$-holes have transmissivity values of
1,600-3,200 meters squared per day, horizontal hydraulic conductivity values of $6.5-13$ meters per day, vertical hydraulic conductivity values of $0.2-1.7$ meters per day, storativity values of $0.001-0.003$, and specific yield values of $0.01-0.2$.

\section{INTRODUCTION}

Information in this report is presented as part of ongoing investigations by the U.S. Geological Survey (USGS) regarding the hydrologic and geologic suitability of Yucca Mountain, Nev., as a potential site for the storage of high-level nuclear waste in an underground mined geologic repository. This investigation, part of the Yucca Mountain Project (YMP), was conducted in cooperation with the U.S. Department of Energy under Interagency Agreement

DE-AI08-92NV10874.

\section{Purpose and Scope}

This report presents information obtained from a multiple-well interference test (henceforth called a pumping test) conducted in Miocene tuffaceous rocks at the C-hole complex (fig. 1) from May 22 to June 12, 1995. Background information for the pumping well, 7 observation wells, and 2 barometers monitored during the test, water-level and atmospheric-pressure data obtained during the test, and analyses of drawdown and recovery in the observation wells are 
presented. Test results are interpreted in the context of previous aquifer-test results in the $\mathrm{C}$-holes that are discussed by Geldon (1996).

The pumping test discussed in this report was designed to determine hydrologic properties of the composite geologic section in each of the $\mathrm{C}$-holes from the bottom of casing and concrete to the total depth of the well. The average thickness of this section is about $486 \mathrm{~m}$, and the top of the section is about $15 \mathrm{~m}$ below the water table at the C-hole complex. Analytical results of this pumping test were intended to verify the accuracy of hydrologic properties calculated from aquifer tests conducted at the C-hole complex in 1984 using less sophisticated equipment emplaced with less knowledge of borehole hydrogeology (Geldon, 1996). The current test also was intended to provide constraints on hydrologicproperty calculations from planned aquifer tests of discrete zones in the $\mathrm{C}$-holes.

\section{Previous work}

Geldon (1993) discussed the layout, construction, geology, rock-matrix properties, and water chemistry of the C-holes and provided a conceptual model of the occurrence and movement of water in the C-holes. Falling-head and pressure-injection tests were done in borehole UE-25 $\mathrm{c \# l}$ in 1983 to develop a hydraulic-conductivity profile of the borehole. A constant-flux injection test in borehole UE-25 c\#2, monitored in borehole UE-25 $\mathrm{c \# 3}$, was done in 1984 to determine hydrologic properties of the Calico Hills Formation and Crater Flat Group (of Sawyer and others, 1994). Three pumping tests were conducted in 1984 in boreholes UE-25 c\#2 and UE-25 c\#3, using the other C-holes as observation wells, to determine hydrologic properties of discrete intervals within the Calico Hills Formation and Crater Flat Group. Geldon (1996) analyzed and interpreted the 1983-84 aquifer tests, integrating borehole geophysical logs and flow surveys conducted from 1983 to 1992 into the analyses.

\section{Methods}

It was not known prior to the pumping test which analytical method would be most appropriate for either the composite sections of the $\mathrm{C}$-holes being tested or observation wells distant from the C-hole complex. Geldon (1996) found that specific intervals in the $\mathrm{C}$-holes responded to pumping in different ways that were consistent with the geology of the intervals and their distance below the top of the saturated zone. An unconfined-aquifer response to pumping is characteristic of rock in the $C$-holes to a depth of about $685 \mathrm{~m}$. Between depths of about 725 and $790 \mathrm{~m}$, rock in the $\mathrm{C}$-holes functions as a nonleaky, confined aquifer in response to pumping. Below a depth of about $815 \mathrm{~m}$, fractures related to faults that intersect the $\mathrm{C}$-holes provide recharge in response to pumping, and the rock in this interval functions as a leaky, confined aquifer. Therefore, it was felt that selection of a particular analytical method or methods for the $\mathrm{C}$-holes should be governed by any aquifer response consistent with those typical of the responses of individual intervals within the $\mathrm{C}$-holes.

It was expected that observation wells beyond the C-hole complex were too far away to be affected by flow from fractures detected in the C-holes. Generally in the same structural block as the C-holes (as noted later, USW H-4 is not), the outlying observation wells were not expected to show the effects of recharge or discharge from block-bounding faults. Mainly on the basis of these spatial and structural factors, the outlying observation wells were anticipated to exhibit a nonleaky, confined aquifer response to pumping in borehole UE-25 $\mathrm{c} \# 3$.

The four analytical methods used in this study, on the basis of considerations discussed in the preceding paragraphs, are those of Neuman (1975), for an infinite, homogeneous, anisotropic, unconfined aquifer; Cooper (1963), for a leaky, homogeneous, isotropic, confined aquifer; Theis (1935), for an infinite, homogeneous, isotropic, confined aquifer, and Cooper and Jacob (1946), for an infinite, homogeneous, isotropic, confined aquifer. Because assumptions, equations, and application of the analytical methods used in this study are discussed fully by Geldon (1996), this discussion is curtailed herein.

\section{Acknowledgments}

The authors are indebted to William B. Distel, Woodward-Clyde Federal Services, for procuring the pump and arranging for the test to proceed; Russell L. Patterson, U.S. Department of Energy, for coordinating field assignments and distributing information 


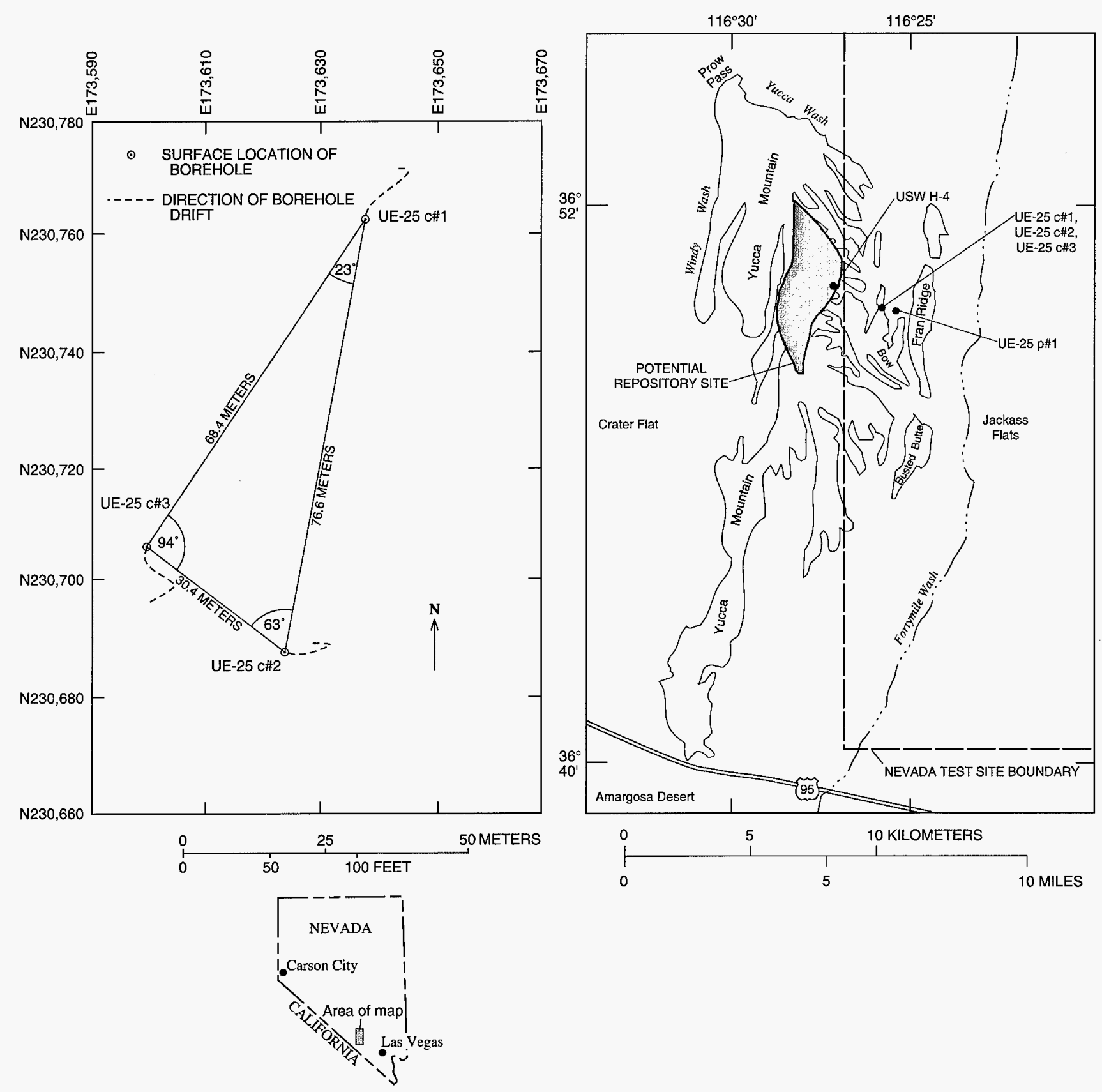

Figure 1. Location of the C-hole complex, boreholes UE-25 c\#1, UE-25 c\#2, and UE-25 c\#3 (C-hole map is referenced to Nevada State, Zone 2, coordinates). 
among the many organizations that participated in the test; Kenzi Karasaki and Barry Freifeld, Lawrence Berkeley National Laboratory, for consultations regarding pressure transducers and other equipment used in the test; and J.N. Stellavato, Nye County Nuclear Waste Repository Project Office, for providing background information on borehole UE-25 ONC-1 and unpublished data obtained from the borehole during the test.

The authors also recognize the contributions of many employees of the USGS who volunteered time and effort beyond the scope of their routine duties to make this study possible. Robert Graves and Robert Goemaat provided unpublished water-level altitude data from the Yucca Mountain ground-water monitoring network. William Steinkampf and Shannon Mahan collected water samples for laboratory analyses and made field or laboratory determinations of several constituents or properties of the water samples.

Shannon Mahan and Diana Perfect assisted the authors in monitoring the data acquisition system and pump discharge during the test.

\section{PHYSICAL SETTING}

The C-hole complex is located in Nye County, Nev., at the western edge of the Nevada Test Site, about $145 \mathrm{~km}$ northwest of Las Vegas (fig.1). The $\mathrm{C}$-holes are in a channel of an ephemeral stream that cuts through Bow Ridge, a spur of Yucca Mountain (fig. 2). Yucca Mountain is situated in the Basin and Range physiographic province. Typical of the Basin and Range province, the area around the C-holes is characterized by narrow, predominantly northtrending mountain ranges and broad alluvial basins (Frizzell and Shulters, 1990).

The C-holes are completed in Miocene tuffaceous rocks (table 1 ), that are covered by a thin veneer $(0-24 \mathrm{~m})$ of Quaternary alluvium and underlain by Paleozoic formations composed mostly of limestone and dolomite (Carr and others, 1986; Scott, 1990). The Miocene tuffaceous rocks consist of nonwelded to densely welded ash-flow tuff with intervals of ash-fall tuff and volcaniclastic rocks. The tuffaceous rocks are pervaded by tectonic and cooling fractures that strike predominantly north-northeast to north-northwest and dip westward at angles of $50^{\circ}-87^{\circ}$. On the basis of surface geology, scattered borehole logs, topography, and the estimated dip of the contact between the Miocene and Paleozoic rocks, the Miocene rocks are estimated to be 1,040-1,590 m thick in the vicinity of the C-holes.

Northerly and northwesterly trending, high-angle faults, such as the Paintbrush Canyon, Midway Valley, and Bow Ridge Faults have offset and tilted the Miocene tuffaceous rocks in the vicinity of the C-holes (fig. 3). The dip of the Miocene tuffaceous rocks increases from $5^{\circ}-10^{\circ}$ eastward at the crest of Yucca Mountain to about $20^{\circ}$ eastward at the C-hole complex (Scott and Bonk, 1984; Frizzell and Shulters, 1990).

At the C-hole complex, the north-striking Midway Valley or Paintbrush Canyon Fault downdropped Miocene tuffaceous rocks to the west. The Miocene tuffaceous rocks and the Midway Valley or Paintbrush Canyon Fault later were downdropped to the northeast by a northwest-striking fault. Geldon $(1993,1996)$ identified these two faults as the Paintbrush Canyon Fault and a high-angle reverse fault, but this interpretation has been modified by recent 1:6,000-scale geologic mapping in the area of the C-holes by Day and others (in press).

Hydrogeologic and hydrochemical data and numerical models for the Yucca Mountain area indicate that ground water in the area flows locally from block-faulted mountains to intermontane basins and regionally from basin to basin toward Alkali Flat (Franklin Lake Playa), Ash Meadows, Oasis Valley, and Death Valley (Luckey and others, 1996). Locally, ground water flows mainly through Tertiary volcanic and tuffaceous rocks and Quaternary and Tertiary alluvium and lacustrine deposits. Ground water flows from basin to basin mainly through Paleozoic carbonate rocks (Plume and Carlton, 1988; Prudic and others, 1993).

The Miocene tuffaceous rocks in the area of the C-hole complex comprise a single, fissure-block aquifer in which the volume and direction of ground-water flow are controlled mainly by the proximity to faults, fracture zones, and partings (Geldon, 1993, 1996). In the vicinity of the C-holes, a ground-water divide centered on Bow Ridge and Boundary Ridge is interpreted to direct flow southward to Dune Wash, northward to Midway Valley, and eastward to Fortymile Wash (fig. 4). Flow from the west into the area of the $\mathrm{C}$-holes is believed to be inhibited by numerous north-striking faults, of which the most prominent is the Solitario Canyon Fault (Tucci and Burkhardt, 1995). The Solitario Canyon 


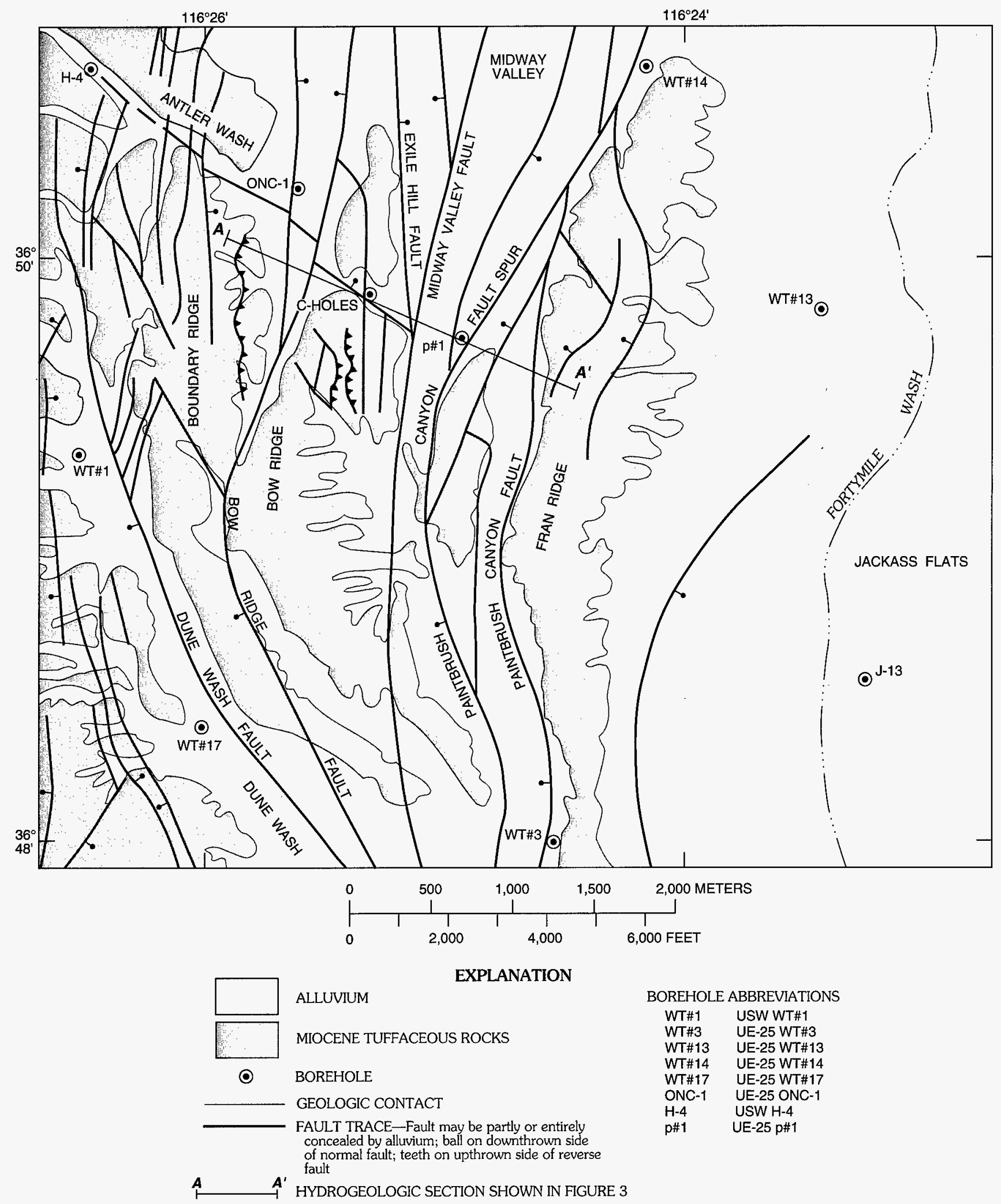

Figure 2. Generalized geologic map showing location of the C-hole complex and nearby boreholes (geology modified from Day and others, in press). 
Table 1. Stratigraphy of Miocene tuffaceous rocks in the C-hole area (Carr and others, 1986; Geldon, 1996; Whitfield and others, 1984)

\begin{tabular}{|c|c|c|c|c|c|}
\hline \multirow{2}{*}{ Geologic unit } & \multicolumn{5}{|c|}{ Depth below land surface, in meters } \\
\hline & USW H-4 & UE-25 c\#1 & UE-25 c\#2 & UE-25 c\#3 & UE-25 p\#1 \\
\hline \multicolumn{6}{|l|}{ Timber Mountain Group } \\
\hline Rainier Mesa Tuff & not present & not present & not present & not present & $39-55$ \\
\hline \multicolumn{6}{|l|}{ Paintbrush Group } \\
\hline Tiva Canyon Tuff & $0-65$ & $0-96$ & $21-88$ & $24-88$ & $55-81$ \\
\hline Topopah Spring Tuff & $65-400$ & $96-406$ & $88-401$ & $88-396$ & $81-381$ \\
\hline Calico Hills Formation & $400-496$ & $406-516$ & $401-510$ & 396-496 & $381-436$ \\
\hline \multicolumn{6}{|l|}{ Crater Flat Group } \\
\hline Prow Pass Tuff & 496-693 & $516-656$ & $510-652$ & $496-644$ & $436-558$ \\
\hline Bullfrog Tuff & $693-812$ & $656-828$ & $652-829$ & 644-814 & $558-691$ \\
\hline Tram Tuff & $812-1,164$ & $828-914^{+}$ & $829-914^{+}$ & $814-914^{+}$ & $691-873$ \\
\hline Lithic Ridge Tuff & $1,164-1,219^{+}$ & not reached & not reached & not reached & $873-1,068$ \\
\hline
\end{tabular}

Fault is interpreted to be a constant-head boundary, whereas discharge areas north, east, and south of the $\mathrm{C}$-hole complex are interpreted to be head-dependent flux boundaries.

Hydrochemical data indicate that the water in the Miocene tuffaceous rocks probably is derived from the Paleozoic carbonate rocks (Geldon, 1993). Under an upward head gradient detected in borehole UE-25 $\mathrm{p} \# 1$, about $630 \mathrm{~m}$ from the C-holes, water in the Paleozoic rocks is believed to rise along faults and related fractures into the upper aquifer.

Depths to water in the vicinity of the C-holes range from about 335 to $520 \mathrm{~m}$ below land surface (O'Brien and others, 1995). Borehole flow surveys, in combination with other geophysical logs, show that flow within the Miocene tuffaceous rocks at the C-hole complex comes from discrete intervals (fig. 5). The total thickness of transmissive intervals identified in the C-holes ranges from 165 to $274 \mathrm{~m}$ (Geldon, 1996). Transmissive intervals in the C-holes contain both fracture and matrix permeability (Geldon, 1996). Fractures in transmissive intervals generally have no preferred orientation, and the fracture density appears to be unrelated to the extent to which tuffaceous rocks in the transmissive intervals are welded (Geldon, 1993). Despite pervasive fracturing, rock in the $\mathrm{C}$-holes consistently responded to pumping and injection tests conducted in 1983-84 as an equivalent porous medium (Geldon, 1996). These aquifer tests indicated that the rock in the C-holes is characterized by layered heterogeneity.

Little is known about hydrologic properties of the Paleozoic carbonate rocks in the vicinity of the $\mathrm{C}$-holes. The closest pumping tests, which were conducted in the Amargosa Desert about $38 \mathrm{~km}$ southeast of the C-hole complex, indicated transmissivity values between 4,800 and $10,800 \mathrm{~m}^{2} / \mathrm{d}$ and a storativity of 0.0005 (Leap and Belmonte, 1992).

\section{PUMPING TEST DESCRIPTION}

A pumping test was conducted in borehole UE-25 c\#3 from May 22 to June 12, 1995. During the test, water-level altitudes were monitored in the pumping well and in boreholes UE-25 $\mathrm{cH1}$, UE-25 c\#2, UE-25 ONC-1, USW H-4, UE-25 WT\#14, UE-25 WT\#3, and UE-25 p\#1 (fig. 2). Atmospheric pressure was monitored during the pumping test at the $\mathrm{C}$-hole complex and at borehole UE-25 ONC-1 to remove barometric effects from collected data. 


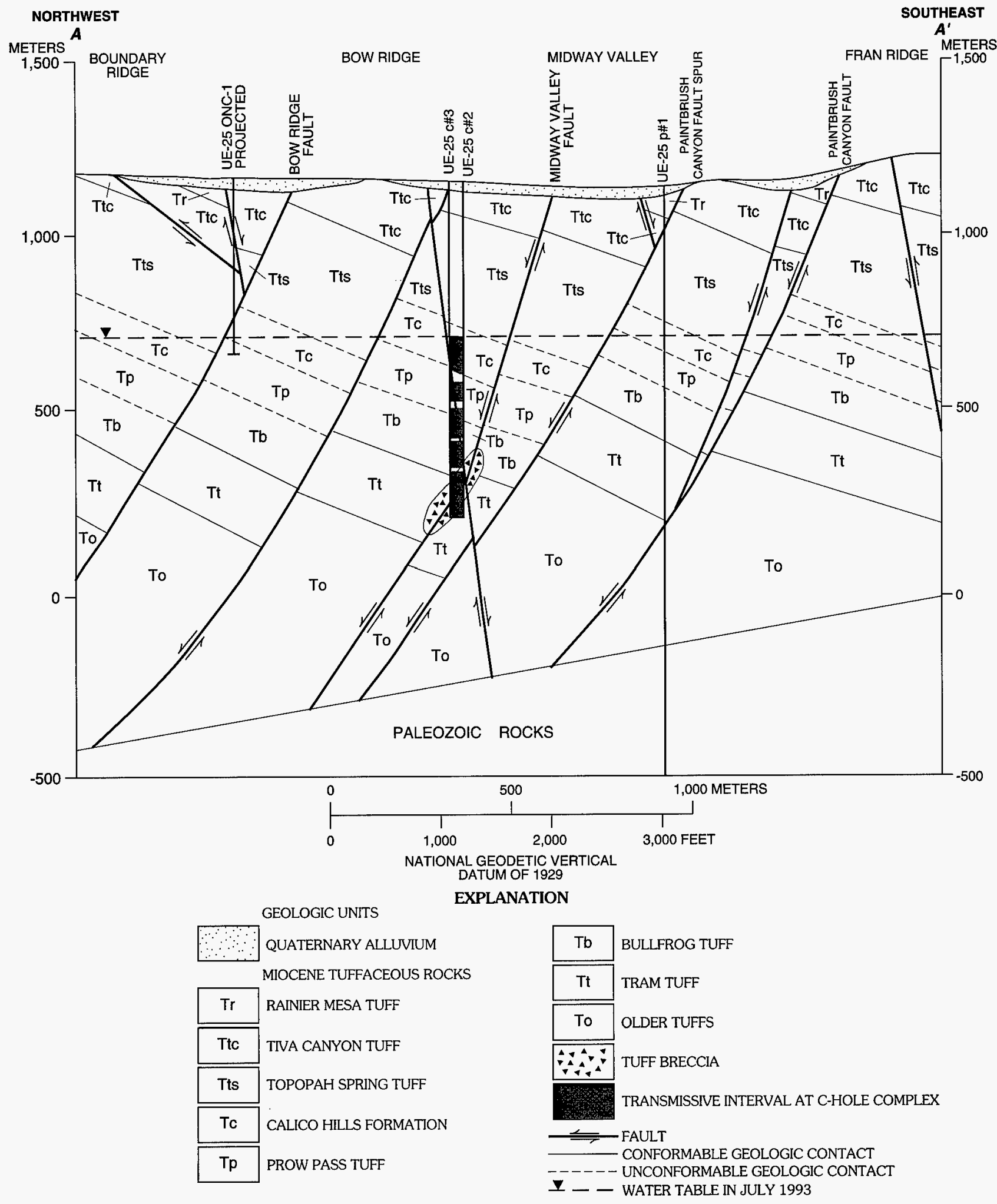

Figure 3. Hydrogeologic section from Boundary Ridge to Fran Ridge (location of section shown in figure 2). 


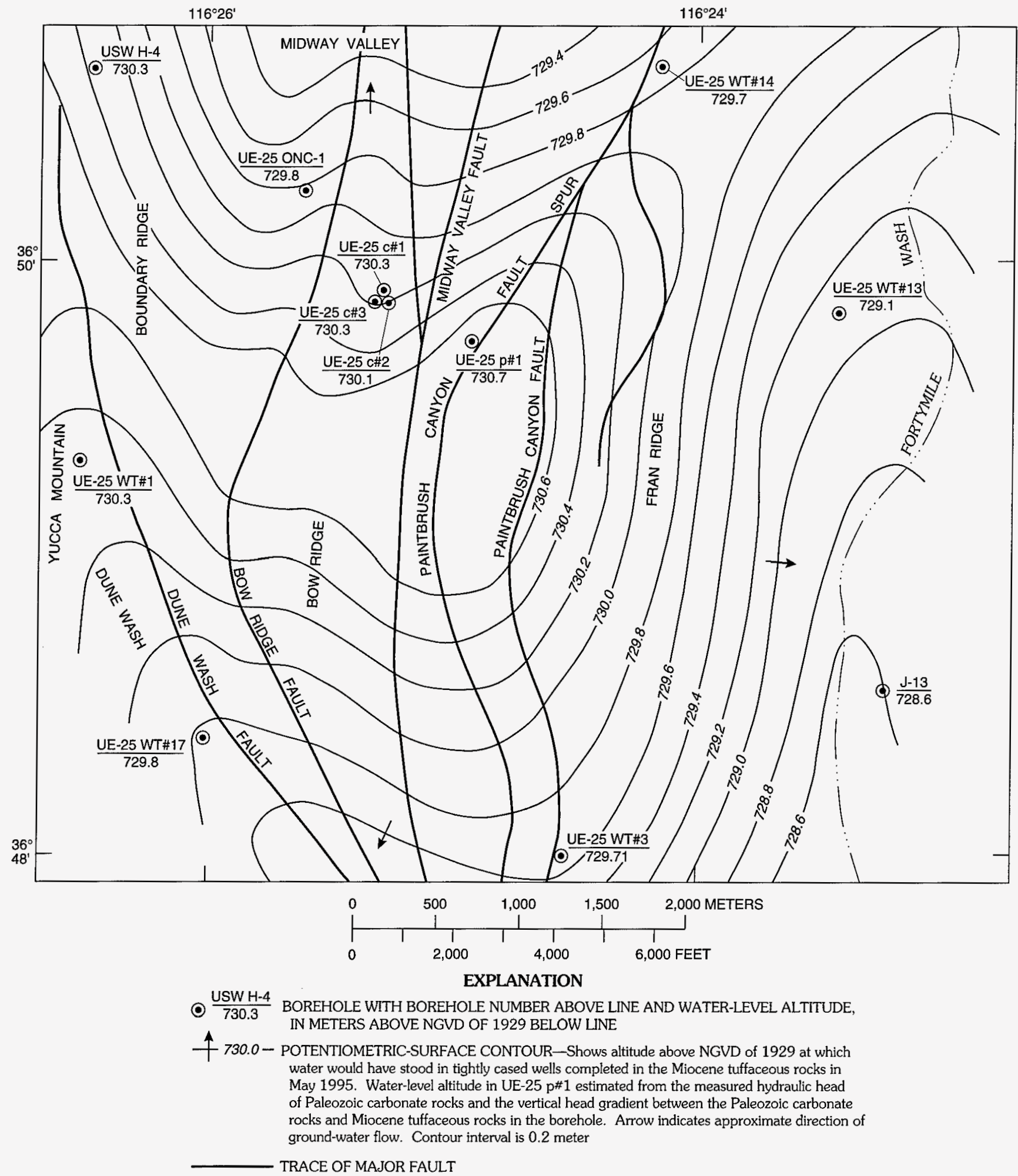

Figure 4. Potentiometric surface of the Miocene tuffaceous rocks in the vicinity of the C-hole complex, May 1995 (water-level altitudes from Graves and others, 1997; Nye County Nuclear Waste Repository Project Office, 1995). 


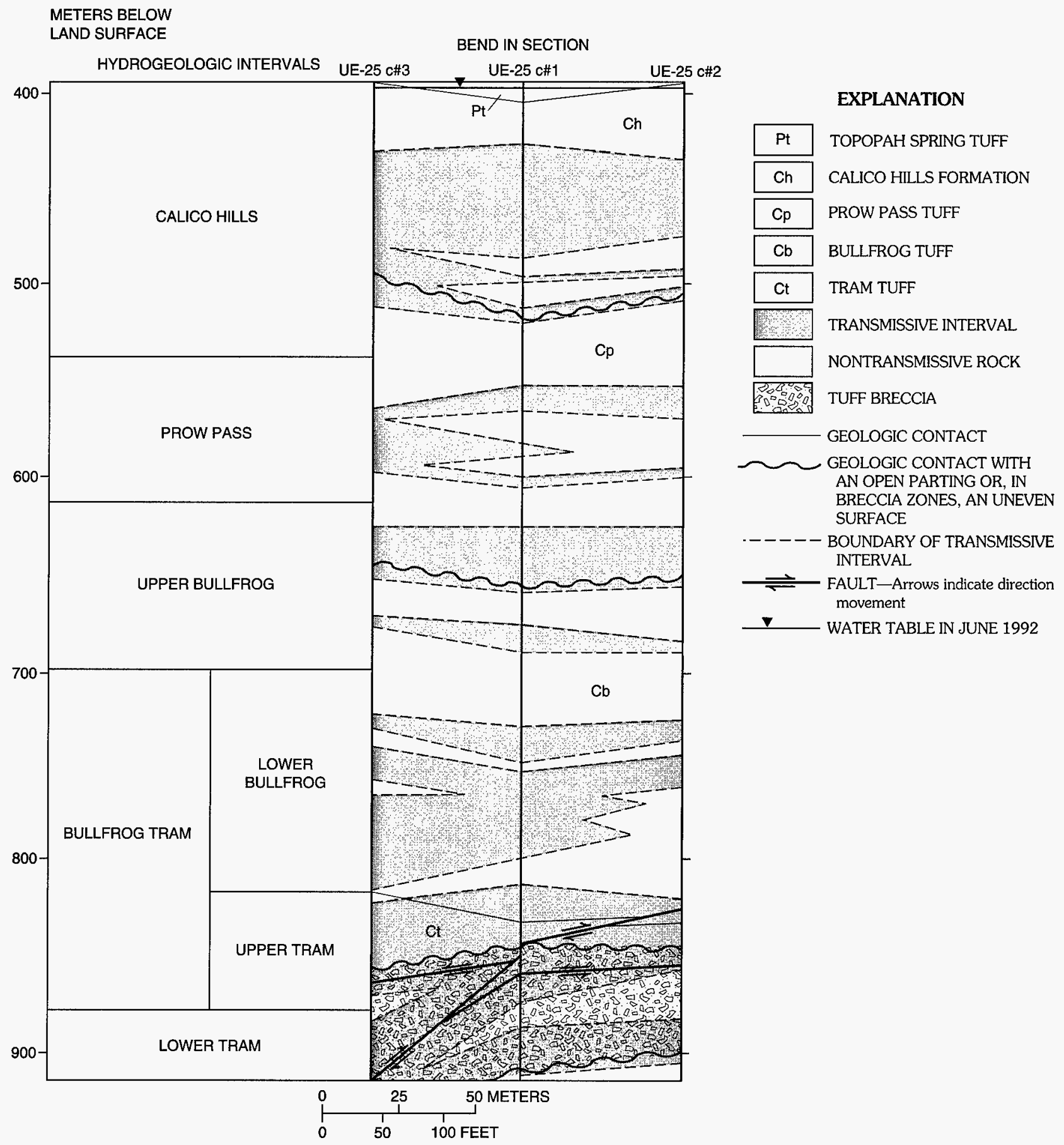

Figure 5. Hydrogeologic intervals in the C-holes, May 1995 to August 1996 (modified from Geldon, 1996). 


\section{Monitoring Network}

The C-holes are 30.4-76.6 $\mathrm{m}$ apart at the surface (fig. 1), although interborehole distances vary substantially at depth because of borehole drift in different directions during drilling. For example, borehole UE-25 c\#1 is $68.4 \mathrm{~m}$ from borehole UE- $25 \mathrm{c \#} 3$ at the land surface, but it is $82.6 \mathrm{~m}$ from UE-25 $\mathrm{c} \# 3$ midway between the bottom of casing and concrete and the bottom of the borehole. Borehole UE-25 $\mathrm{c} \# 2$ is $30.4 \mathrm{~m}$ from borehole UE-25 c\#3 at the land surface, but it is $29.0 \mathrm{~m}$ from UE- $25 \mathrm{c} \# 3$ midway between the bottom of casing and concrete and the bottom of the borehole. Under the assumption of radial flow between observation wells and the pumping well, interborehole distances at the midpoints of the open sections of the C-holes were used in analysis of the pumping test.

During the pumping test, each of the C-holes was open in the Calico Hills Formation, and the Prow Pass, Bullfrog, and Tram Tuffs of the Crater Flat Group. Borehole UE-25 c\#3 was open from the bottom of casing and concrete, at a depth of $417.0 \mathrm{~m}$, to where the bottom of the borehole has collapsed. Total depth was determined to be $900.4 \mathrm{~m}$ in June 1992. A $25-\mathrm{L} / \mathrm{s}$-capacity pump with an intake at a depth of $450.2 \mathrm{~m}$ (48.2 m below the water-level altitude prior to pumping) was suspended in the borehole on 14-cm-diameter pipe. The pump was powered by two generators operating in parallel, and the pump discharge was regulated by a varispeed controller connected to the generators. The pipe on which the pump was suspended was connected at the wellhead to a 15-cm-diameter discharge line that extends about 8 $\mathrm{km}$ to a buried leachfield in Fortymile Wash. Instantaneous and cumulative discharges were recorded at the wellhead by a calibrated in-line flowmeter. An absolute pressure transducer attached to the pipe in borehole UE-25 c\#3 at a depth of about $441.1 \mathrm{~m}$ and a barometer installed in a trailer near the borehole were used to obtain water-level altitudes during the test. The flow meter, pressure transducer, and barometer were connected to a computer with software installed for realtime data monitoring and storage.

Borehole UE-25 $\mathrm{c \# 1}$ was open during the pumping test from the bottom of casing and concrete, at a depth of $417.9 \mathrm{~m}$, to where the bottom of the borehole has collapsed. Total depth was determined to be $897.6 \mathrm{~m}$ in December 1990. Five dual-mandrel packers installed on 7.3-cm-diameter drill pipe were deflated during the test to allow hydraulic communication from all transmissive intervals in the borehole. An absolute pressure transducer attached to the drill pipe at a depth of about $552.0 \mathrm{~m}$ and the barometer at the C-hole complex were used to obtain water-level altitudes during the test. The pressure transducer was connected to the same data acquisition system as the electronic equipment in borehole UE-25 c\#3.

Borehole UE-25 $\mathrm{c \# 2}$ was open during the pumping test from the bottom of casing and concrete, at a depth of $416.0 \mathrm{~m}$, to where the bottom of the borehole has collapsed. Total depth was determined in June 1992 to be $910.1 \mathrm{~m}$. Five dual-mandrel packers installed on 7.3-cm-diameter drill pipe were deflated during the test to allow hydraulic communication from all transmissive intervals in the borehole. An absolute pressure transducer attached to the drill pipe at a depth of about $610.4 \mathrm{~m}$ and the barometer at the C-hole complex were used to obtain water-level altitudes during the test. The pressure transducer was connected to the same data acquisition system as the electronic equipment in boreholes UE-25 c\#1 and UE-25 c\#3.

Borehole UE-25 ONC-1, drilled and instrumented by Nye County (Nye County Nuclear Waste Repository Project Office, 1995), is $842.8 \mathrm{~m}$ from borehole UE-25 c\#3 at the land surface and is $469.4 \mathrm{~m}$ deep (about $36.3 \mathrm{~m}$ below the water-level altitude in the borehole). The borehole is telescoped downward and has a diameter of about $13 \mathrm{~cm}$ in the saturated zone. Seven packers inflated between the bottom of casing and a depth of $409.6 \mathrm{~m}$ separate the unsaturated and saturated zones; another packer emplaced at a depth of 451.7-453.2 m divides the saturated zone into two intervals. The upper of the saturated-zone intervals is open in the Calico Hills Formation and Prow Pass Tuff; the lower of these intervals is open in the Prow Pass Tuff. Absolute pressure transducers installed at depths of 450.2 and $457.7 \mathrm{~m}$ and a barometer installed at the land surface were used to obtain water-level altitudes during the pumping test. Data recorded by the pressure transducers and barometer were transmitted to, and stored in an electronic data logger.

Four boreholes in the USGS-YMP groundwater monitoring network (O'Brien and others, 1995) were used as observation wells during the pumping test. Borehole UE-25 WT\#3, which is $3,525.6 \mathrm{~m}$ from borehole UE-25 c\#3 at the land surface, is $348.1 \mathrm{~m}$ deep (about $47.5 \mathrm{~m}$ below the water-level altitude in 
the borehole) and is open in the Bullfrog Tuff. Borehole UE-25 WT\#14, which is $2,249.1 \mathrm{~m}$ from borehole $\mathrm{UE}-25 \mathrm{c} \# 3$ at the land surface, is $399.0 \mathrm{~m}$ deep (about $52.7 \mathrm{~m}$ below the water-level altitude in the borehole) and is open in the Topopah Spring Tuff and Calico Hills Formation. Borehole USW H-4, which is 2,245.2 $\mathrm{m}$ from borehole UE-25 $\mathrm{c} \# 3$ at the land surface, is $1,219.2 \mathrm{~m}$ deep and contains a packer at a depth of $1,181.1 \mathrm{~m}$ to separate the Prow Pass, Bullfrog, Tram, and upper Lithic Ridge Tuffs from the lower Lithic Ridge Tuff. The water-level altitude is about $730.3 \mathrm{~m}$ in the upper part of borehole USW H-4.

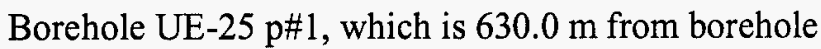
UE-25 c\#3 at the land surface, is $1,805.3 \mathrm{~m}$ deep, but casing and concrete emplaced to a depth of $1,297.2 \mathrm{~m}$ isolate Miocene tuffaceous rocks in the upper part of the borehole from Silurian carbonate rocks in the lower part of the borehole. The water-level altitude for the Silurian carbonate rocks in UE-25 p\#1 is about $752.6 \mathrm{~m}$, which is $22-23 \mathrm{~m}$ higher than water-level altitudes for the Miocene tuffaceous rocks in the C-hole area.

All USGS-YMP network boreholes monitored during the pumping test have gage transducers installed to obtain data that can be converted to water-level altitudes, as described by O'Brien and others (1995). The transducers are connected to data collection platforms, from which data are transmitted via satellite to USGS computers. During the test, transducers in the USGS-YMP network boreholes that were used as observation wells were programmed to record data every 10-15 minutes. These data subsequently were converted to water-level altitudes by USGS-YMP network personnel. At the time of this writing, this information was unpublished.

\section{Atmospheric Pressure, Earth Tides, and Barometric Efficiency}

Atmospheric pressure was recorded at two sites during the pumping test - the C-hole complex and borehole UE-25 ONC-1. Recorded in pounds per square inch, atmospheric-pressure data were converted to meters of water for analytical purposes by the following equation (derived from the variation in the density of water with temperature at 1 atmosphere, as listed by Streeter and Wylie, 1975):

$$
\begin{gathered}
\mathrm{P}_{\mathrm{m}}=0.3048 \times(2.3064+0.000031866 \times \\
\left.\mathrm{T}+0.0000098745 \times \mathrm{T}^{2}\right) \times \mathrm{P}_{\mathrm{psi}}
\end{gathered}
$$

where $P_{m}=$ pressure, in meters of water;

$\mathrm{T}=$ water temperature, in degrees Celsius; and $\mathrm{P}_{\mathrm{psi}}=$ pressure, in pounds per square inch (psi).

A conversion factor of $0.707 \mathrm{~m} / \mathrm{psi}$ was used, because average water temperatures in the $\mathrm{C}$-holes were $35.2-41.8^{\circ} \mathrm{C}$ during the pumping test.

As shown in figure 6, high atmospheric pressure moved into the vicinity of the $\mathrm{C}$-holes during the first 8.74 days of the pumping test. From 8.74 to 10.18 days after pumping started (during which time, the pump was shut off), low atmospheric pressure moved into the vicinity of the C-holes. Weather-system movements caused several additional changes in atmospheric pressure during the remainder of the pumping test. Superimposed on weather-system related effects, semidiurnal heating and cooling of the atmosphere caused fluctuations in atmospheric pressure of generally less than $3 \mathrm{~cm}$ during the period of record.

Each increase or decrease in atmospheric pressure caused water-level altitudes in monitored wells to change inversely, independently of any changes that might have been induced by pumping. For each monitored well, these barometric effects were removed from recorded water-level altitudes by determining the barometric efficiency of the well and subtracting atmospheric-pressure changes multiplied by the barometric efficiency from recorded changes in water-level altitudes (as discussed in Bureau of Reclamation, 1981).

To determine the barometric efficiency of the C-holes from the bottom of casing and concrete to total depth, simultaneous records of water-level altitudes in boreholes UE-25 c\#1 and UE-25 c\#3 and atmospheric pressures at a weather station $5.3 \mathrm{~km}$ from the C-hole complex (WX-3) were obtained from July 15 to September 8, 1993 (Geldon and others, 1997). A low-pass filter with a frequency of 0.8 cycles/day was applied to the water-level and atmospheric-pressure data to remove Earth-tide effects. Subsequently, changes in filtered water-level altitudes were plotted as a function of changes in filtered atmospheric pressures for boreholes UE-25 c\#1 and UE-25 c\#3 (fig. 7). The slopes of the regression lines are the barometric efficiency values for 


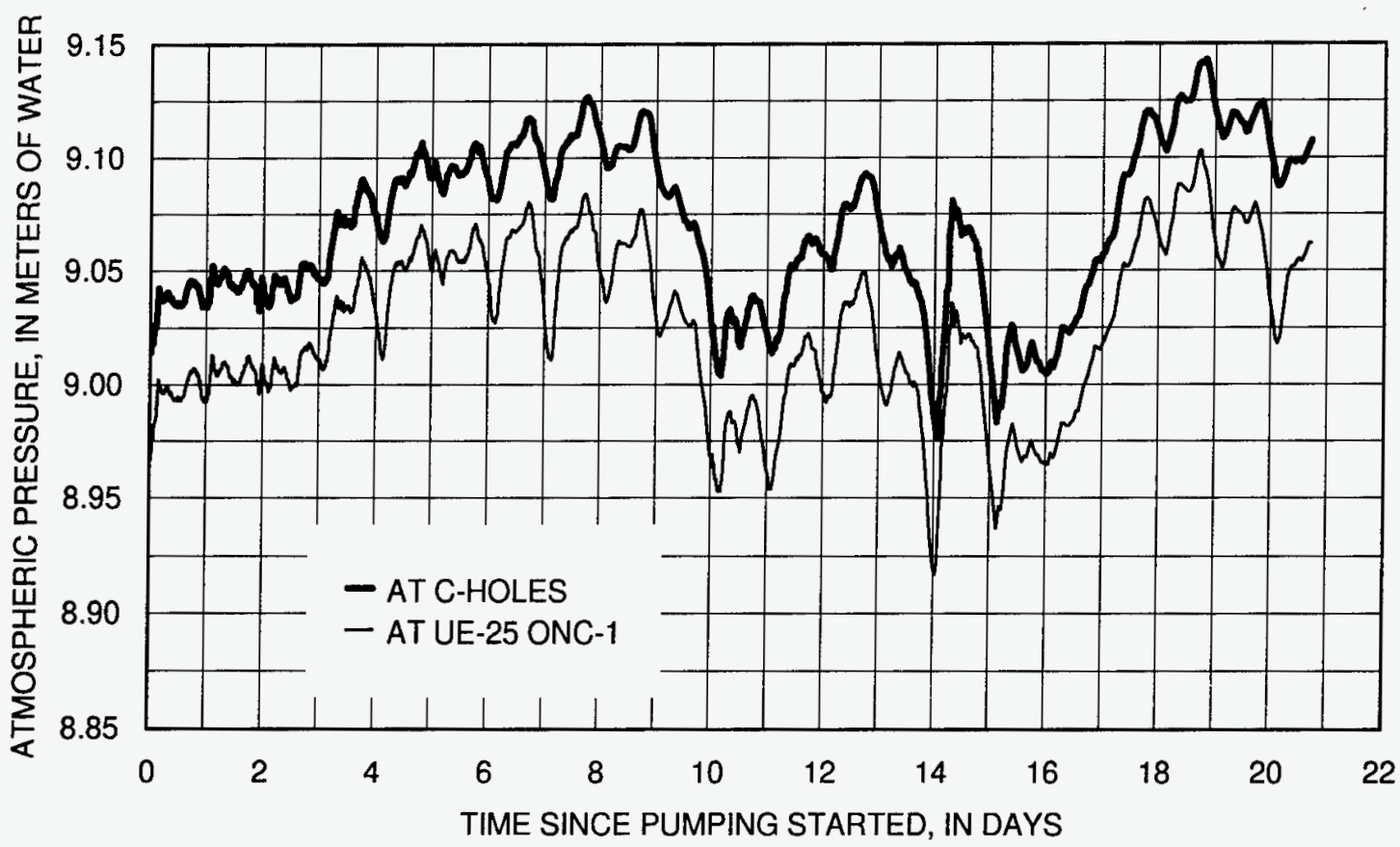

Figure 6. Atmospheric pressure at the C-hole complex and at borehole UE-25 ONC-1, May-June 1995.

UE-25 $\mathrm{c} \# 1$ and UE-25 $\mathrm{c} \# 3$. These values ranged from 0.93 to 0.95 and averaged 0.94 . In contrast, Galloway and Rojstaczer (1988) determined the barometric efficiency of borehole UE-25 $\mathrm{p} \# 1$ to be 0.75 .

The barometric efficiency of borehole UE-25

ONC-1 was determined from simultaneous records of water-level altitudes in the lowest packed off interval in the borehole and atmospheric pressures recorded by a barometer located at the borehole. Data were obtained May 12-17, 1995 (prior to pumping). After filtering the data to remove Earth-tide-induced fluctuations, a plot of changes in water-level altitude as a function of changes in atmospheric pressure indicated a barometric efficiency of 0.99 .

Barometric efficiency values for boreholes USW H-4, UE-25 WT\#14, and UE-25 WT\#3 were determined from water-level altitudes in these boreholes and atmospheric pressures recorded at either the C-hole complex or borehole UE-25 ONC-1 after the drawdown caused by pumping borehole UE- $25 \mathrm{c \# 3}$ during the test discussed in this report had dissipated. The period of record for these determinations was 4-8 days; barometric efficiency values ranged from 0.89 to 0.91 (table 2).

With periods of 12-26 hours (Galloway and Rojstaczer, 1988), Earth tides caused fluctuations of less than $0.12 \mathrm{~m}$ in the water-level altitudes in observation wells used during the pumping test. Earth-tide effects were small enough to be ignored in analyzing drawdown and recovery in the $\mathrm{C}$-holes and borehole UE-25 ONC-1. However, Earth-tide effects were expected to be similar in magnitude to barometric- and pumping-induced changes in water-level altitudes in the other observation wells and, thus, had to be removed from water-level altitudes to avoid obscuring any analyzable pumping stresses in these boreholes. Earth-tide effects were removed from water-level altitudes obtained from boreholes USW H-4, UE-25 WT\#14, UE-25 WT\#3, and UE-25 p\#1 prior to computing drawdown by applying a low-pass filter with a cut-off frequency of 0.8 cycles/day to the water-level altitudes and simultaneously recorded atmospheric pressures.

No attempt was made to obtain an extensive record of pre-test water-level altitudes to correct for long-term trends, because water-level altitudes in boreholes at Yucca Mountain appear to be stable. As stated by Luckey and others (1996), "Once potentiometric levels in a borehole have equilibrated after drilling or reconfiguration of packers, the levels generally change very little with time." 
UE-25 c\#1

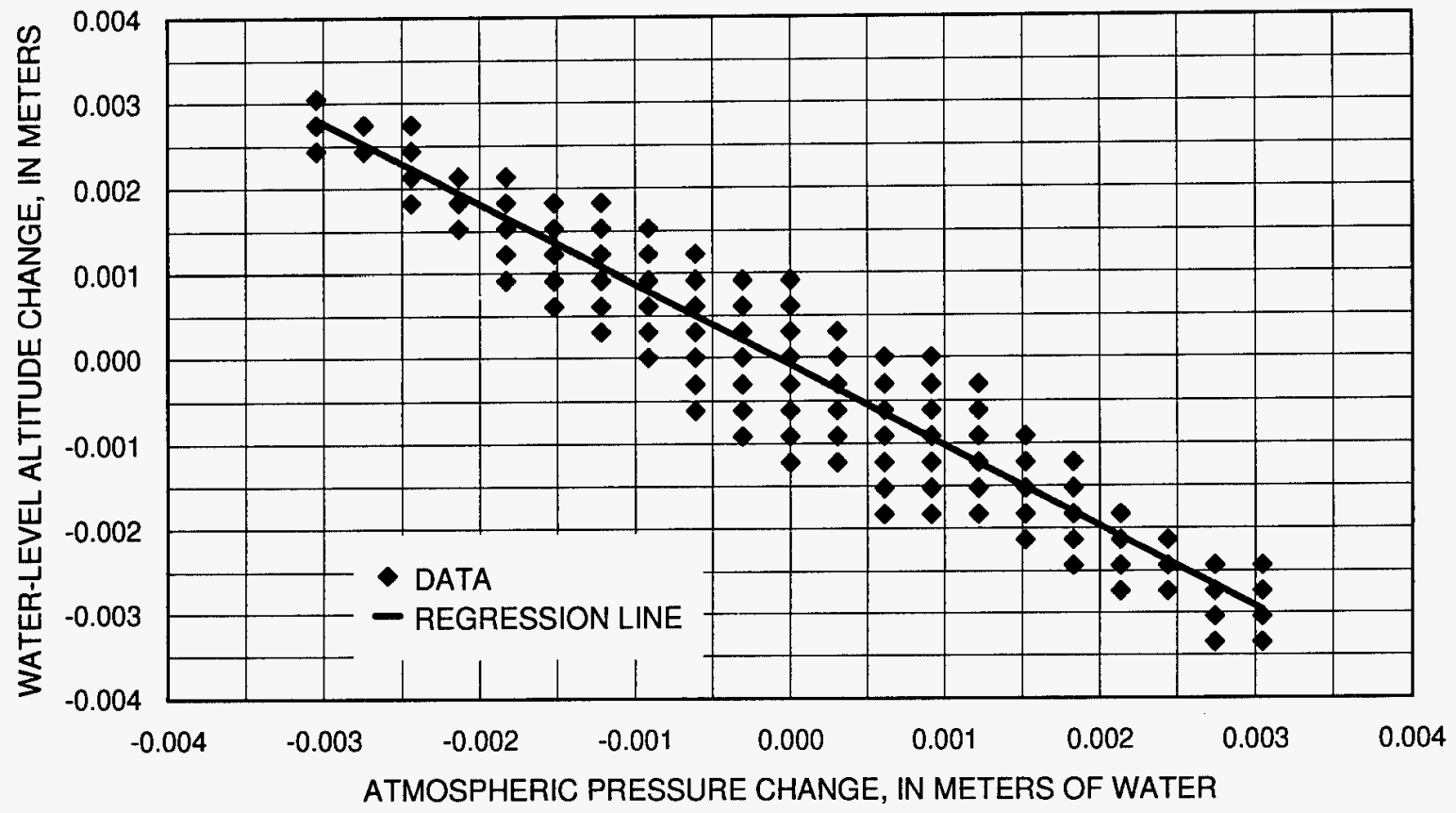

UE-25 c\#3

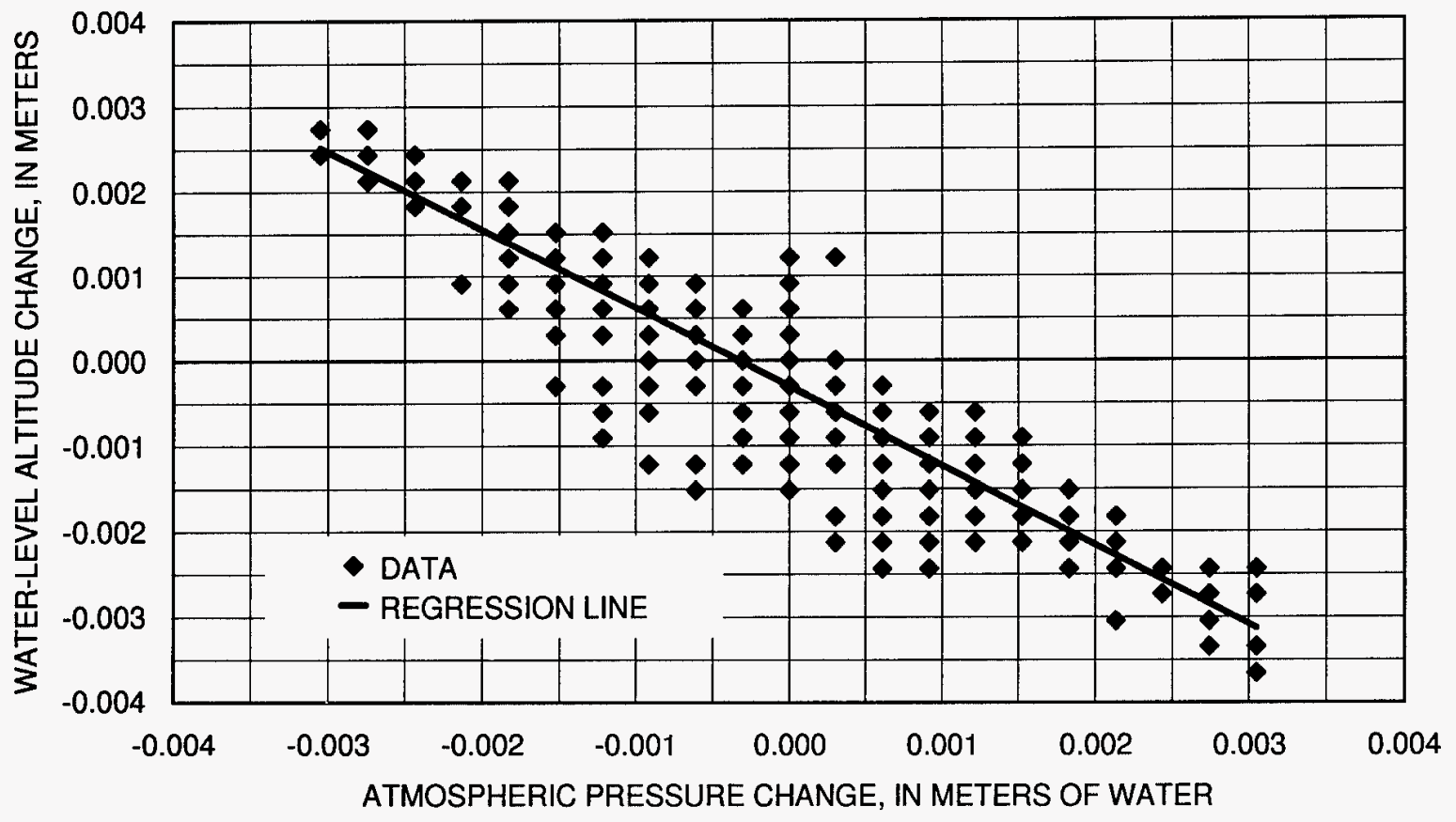

Figure 7. Determination of barometric efficiency in boreholes UE-25 c\#1 and UE-25 c\#3 from changes in water-level altitude and atmospheric pressure July 15-September 8, 1993. 
Table 2. Barometric efficiency values determined for boreholes monitored during the pumping test in borehole UE-25 c\#3, May-June 1995

[NA, not applicable; barometric efficiency for UE-25 $\mathrm{c} \# 2$ estimated from values for UE-25 $\mathrm{c \# 1}$ and UE-25 c\#3; barometric efficiency value for UE-25 p\#1 from Galloway and Rojstaczer (1988)]

\begin{tabular}{lllc}
\hline \multicolumn{1}{c}{ Borehole } & \multicolumn{1}{c}{$\begin{array}{c}\text { Barometer } \\
\text { location }\end{array}$} & \multicolumn{1}{c}{ Period of record } & $\begin{array}{c}\text { Barometric } \\
\text { efficiency }\end{array}$ \\
\hline UE-25 c\#1 & WX-3 & July 15-September 8, 1993 & 0.95 \\
UE-25 c\#2 & NA & NA & .94 \\
UE-25 c\#3 & WX-3 & July 15-August 17, 1993 & .93 \\
UE-25 ONC-1 & UE-25 ONC-1 & May 12-17, 1995 & .99 \\
USW H-4 & UE-25 ONC-1 & June 8-12, 1995 & .91 \\
UE-25 WT\#14 & C-holes & June 4-12, 1995 & .89 \\
UE-25 WT\#3 & C-holes & June 4-12, 1995 & .91 \\
UE-25 p\#1 & C-holes & January 1-June 20, 1986 & .75 \\
\hline
\end{tabular}

\section{Water-Level Altitudes}

Water-level altitudes in boreholes USW H-4, UE-25 WT\#14, UE-25 WT\#3, and UE-25 p\#1 were obtained from a report by Graves and others (1997). Water-level altitudes in the C-holes and borehole UE-25 ONC-1 at any time during the pumping test equaled the water-level altitude in each borehole immediately before the pump was started (the initial water-level altitude) plus the change in pressure head in the borehole since the start of pumping.

Computations of initial water-level altitudes were based on available data. Initial water-level altitudes in the $\mathrm{C}$-holes were determined by adjusting water-level altitudes measured when the boreholes were instrumented prior to the pumping test for changes in atmospheric pressure between these measurements and the start of the test. Water-level altitudes were measured in the $\mathrm{C}$-holes between December 12, 1994, and March 9, 1995, using either a steel tape or a multi-conductor cable unit (see O'Brien, 1991, for descriptions of these devices and measuring techniques). Initial water-level altitudes in borehole UE-25 ONC-1 were determined by adding the pressure heads recorded by the two transducers in the borehole prior to the start of the pumping test to the altitudes of the transducers. Initial water-level altitudes of all observation wells are listed in table 3 .

Pressure heads in the $\mathrm{C}$-holes and borehole UE-25 ONC-1 were obtained by subtracting atmospheric pressures from total pressures recorded concurrently by the transducers in each borehole. Recorded in pounds per square inch, total pressures were converted to meters of water using equation 1 .
Table 3. Initial water-level altitudes in boreholes monitored during the pumping test in borehole UE-25 c\#3, May-June 1995

[Listed water-level altitudes are for May 22, 1995, 2:58 p.m.]

\begin{tabular}{cc}
\hline Borehole & $\begin{array}{c}\text { Water-level altitude } \\
\text { (meters) }\end{array}$ \\
\hline MIOCENE TUFFACEOUS ROCKS \\
UE-25 c\#1 & 730.34 \\
UE-25 c\#2 & 730.12 \\
UE-25 c\#3 & 730.35 \\
UE-25 ONC-1 & \\
Upper zone & 729.78 \\
Lower zone & 729.59 \\
UE-25 WT\#3 & 729.76 \\
UE-25 WT\#14 & 729.70 \\
USW H-4 & 730.37 \\
PALEOZOIC CARBONATE ROCKS \\
UE-25 p\#1 \\
\hline
\end{tabular}

\section{Test Procedures}

Prior to the start of the pumping test, the pump, discharge line, and other equipment were checked for performance, borehole UE- $25 \mathrm{c} \# 3$ was cleaned of debris, and an optimal pumping rate for the test was chosen by operating the pump at varying discharge rates for a relatively brief period. The pump was 
started on May 17, 1995, at 11:31 a.m. and turned off on May 18, 1995, at 1:13 p.m. During this performance test, the discharge rate gradually was increased from 11.3 to $25.0 \mathrm{~L} / \mathrm{s}$. During the 1,542 minutes that the pump was in operation, 2.15 million $L$ of water were withdrawn from borehole UE- $25 \mathrm{c \#} 3$ at an average rate of $23.3 \mathrm{~L} / \mathrm{s}$. Between the performance test and the pumping test, sufficient time was allowed for complete recovery of water-level altitudes in all boreholes.

The pump was restarted for the pumping test at 2:58 p.m. on May 22, 1995, and pumping continued without interruption until 3:01 p.m. on June 1, 1995, a period of 10 days (14,403 minutes). Recovery was monitored from June 1 to June 12, 1995. During the test, 15.36 million $\mathrm{L}$ of water were withdrawn from borehole UE- $25 \mathrm{c} \# 3$ at an average rate of $17.9 \mathrm{~L} / \mathrm{s}$; deviation from the average discharge rate was negligible (fig. 8). The pumping produced a drawdown of about $7.76 \mathrm{~m}$ in UE- $25 \mathrm{cH}, 90$ percent of which occurred within 10 minutes of the pump being turned on (fig. 9). Recovery after the pump was turned off was equally rapid.

As indicated by analyses of aquifer tests conducted in boreholes UE-25 c\#2 and UE-25 c\#3 during 1984 (Geldon,1996), magnitudes of drawdown and recovery in pumping and injection wells at the C-hole complex probably can be attributed to either "borehole skin" or frictional head loss and cannot be used to determine hydrologic properties of the aquifer being tested. Only the drawdown and recovery measured in observation wells can be used to determine hydrologic properties. During the pumping test, water-level-altitude changes in observation wells, uncorrected for barometric and Earth-tide effects, ranged from 0.13 to $0.53 \mathrm{~m}$ (figs. $10-12$ ).

\section{PUMPING TEST ANALYSIS}

Corrected for atmospheric-pressure change and, where necessary, Earth-tide effects, drawdown in the 6 observation wells completed in the Miocene tuffaceous rocks ranged from 0 to $0.42 \mathrm{~m}, 14,000$ minutes after pumping started. As shown in figure 13, the drawdown was asymmetric, with more drawdown occurring in a west-northwesterly direction from borehole UE-25 c\#3 than at the same distance orthogonally. This drawdown distribution is interpreted to indicate the influence of a northwest-trending zone of discontinuous faults (shown in fig. 2) that extends from Bow Ridge to Antler Wash.

\section{Borehole UE-25 c\#2}

Borehole UE-25 c\#2, $29.0 \mathrm{~m}$ from UE-25 c\#3, was the closest observation well to the pumping well, and drawdown in UE-25 $\mathrm{c \# 2}$ was observed within a minute of the pump being started (fig. 14). Drawdown became constant at about $0.25 \mathrm{~m}$ between 140 and 810 minutes after pumping started. After 810 minutes, drawdown resumed at a progressively decreasing rate and was $0.32 \mathrm{~m}$ when the pump was turned off, 14,403 minutes after pumping started. Complete recovery from pumping occurred about 13,600 minutes after pumping stopped.

Drawdown in borehole UE-25 c\#2 was characteristic of an unconfined aquifer (Walton, 1985). The initial drawdown of $0.25 \mathrm{~m}$ was caused by the release of water from aquifer storage. Between 140 and 810 minutes after pumping started, drawdown stagnated because of gravity drainage from the water table to the aquifer matrix. After 810 minutes of pumping, as the release of water from storage exceeded the rate of gravity drainage, drawdown resumed increasing. As presented by Neuman (1975), the equations relevant to analyzing the drawdown in borehole UE-25 c\#2 are:

$$
\begin{gathered}
\frac{T=Q \times W\left(\mu_{A} \mu_{B} \beta\right)}{4 \pi s} \\
K_{r}=T / B
\end{gathered}
$$

$$
K_{z}=\frac{K_{r} b^{2} \beta}{r^{2}}
$$

$$
\begin{gathered}
S=\frac{4 T t \mu_{A}}{r^{2}} \\
S_{y}=\frac{4 T t \mu_{B}}{r^{2}}
\end{gathered}
$$


where $T=$ transmissivity, in meters squared per day;

$Q$ = discharge, in cubic meters per day;

$W\left(\mu_{A}, \mu_{B}, \beta\right)=$ well function for an unconfined, anisotropic aquifer;

$s=$ drawdown, in meters, corresponding to $\mathrm{W}\left(\mu_{\mathrm{A}}, \mu_{\mathrm{B}}, \beta\right)$;

$K_{r}=$ horizontal hydraulic conductivity, in meters per day;

$K_{z}=$ vertical hydraulic conductivity, in meters per day;

$\beta=a$ dimensionless parameter defined by equation 4;

$b=$ thickness, in meters, of transmissive intervals;

$S=$ storativity (dimensionless);

$S_{y}=$ specific yield (dimensionless);

$\mu_{A}, \mu_{B}=$ dimensionless parameters defined by equations 5 and 6 ;

$t=$ time, in days, corresponding to $\mu_{\mathrm{A}}$ or $\mu_{B}$; and

$r=$ distance, in meters, from the pumping well.
Matched to the type curve for $\beta=0.004$ (fig.14), the drawdown data from borehole UE-25 $\mathrm{c} \# 2$ indicated the following:

$$
T=\frac{17.9 \mathrm{~L} / \mathrm{s} \times 86.4 \mathrm{~m}^{3} / \mathrm{d} \times 1}{4 \times \pi \times 0.058 \mathrm{~m} \times 1 \mathrm{~L} / \mathrm{s}}=2,121.9=2,100 \mathrm{~m}^{2} / d
$$

$K_{r}=\frac{2,121.9 m^{2} / d}{164.9 m}=12.9=13 m / d$

$$
K_{z}=\frac{12.9 \mathrm{~m} / \mathrm{d} \times 0.004 \times(164.9 \mathrm{~m})^{2}}{(29.0 \mathrm{~m})^{2}}=1.67=1.7 \mathrm{~m} / \mathrm{d}
$$

$$
S=\frac{4 \times 2,121.9 \mathrm{~m}^{2} / d \times 3.8 \mathrm{~min} \times x 0.1}{(29.0 \mathrm{~m})^{2} \times 1,440 \mathrm{~min} / d}=0.003
$$

$$
S_{y}=\frac{4 \times 2,121.9 \mathrm{~m}^{2} / d \times 32 \mathrm{~min} \times 1}{(29.0 \mathrm{~m})^{2} \times 1,440 \mathrm{~min} / \mathrm{day}}=0.22=0.2
$$

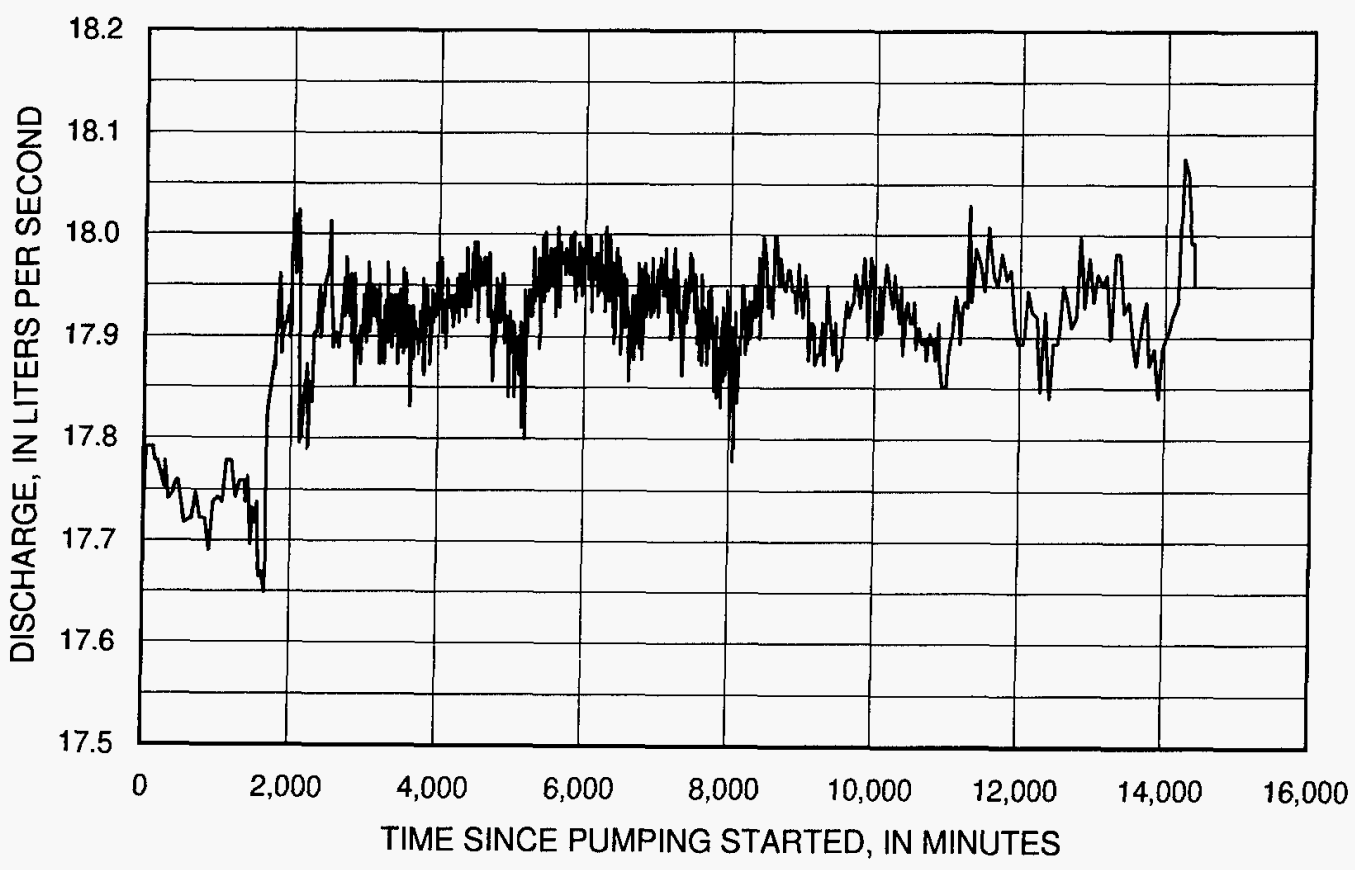

Figure 8. Discharge from borehole UE-25 c\#3, May-June 1995. 


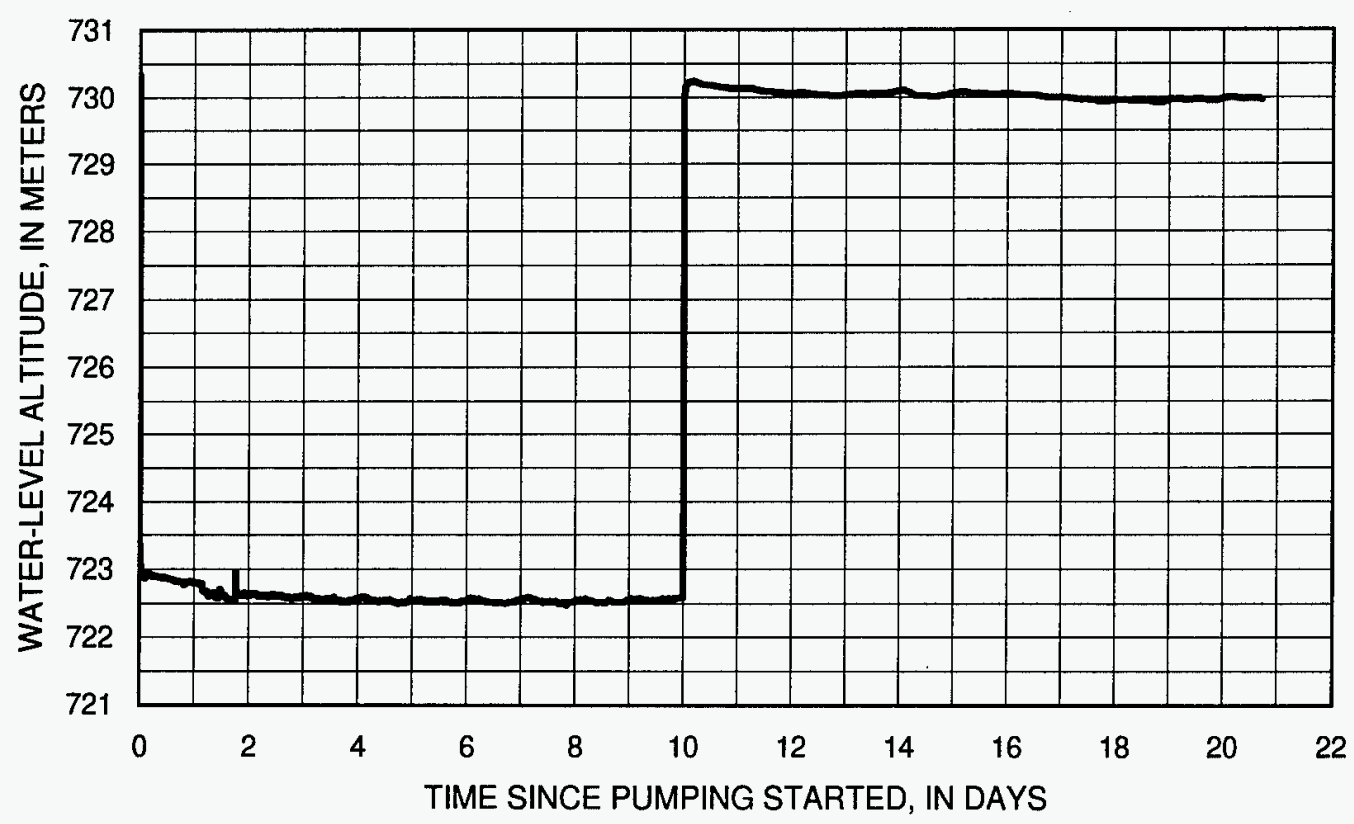

Figure 9. Water-level altitudes in borehole UE-25 c\#3, May-June 1995.

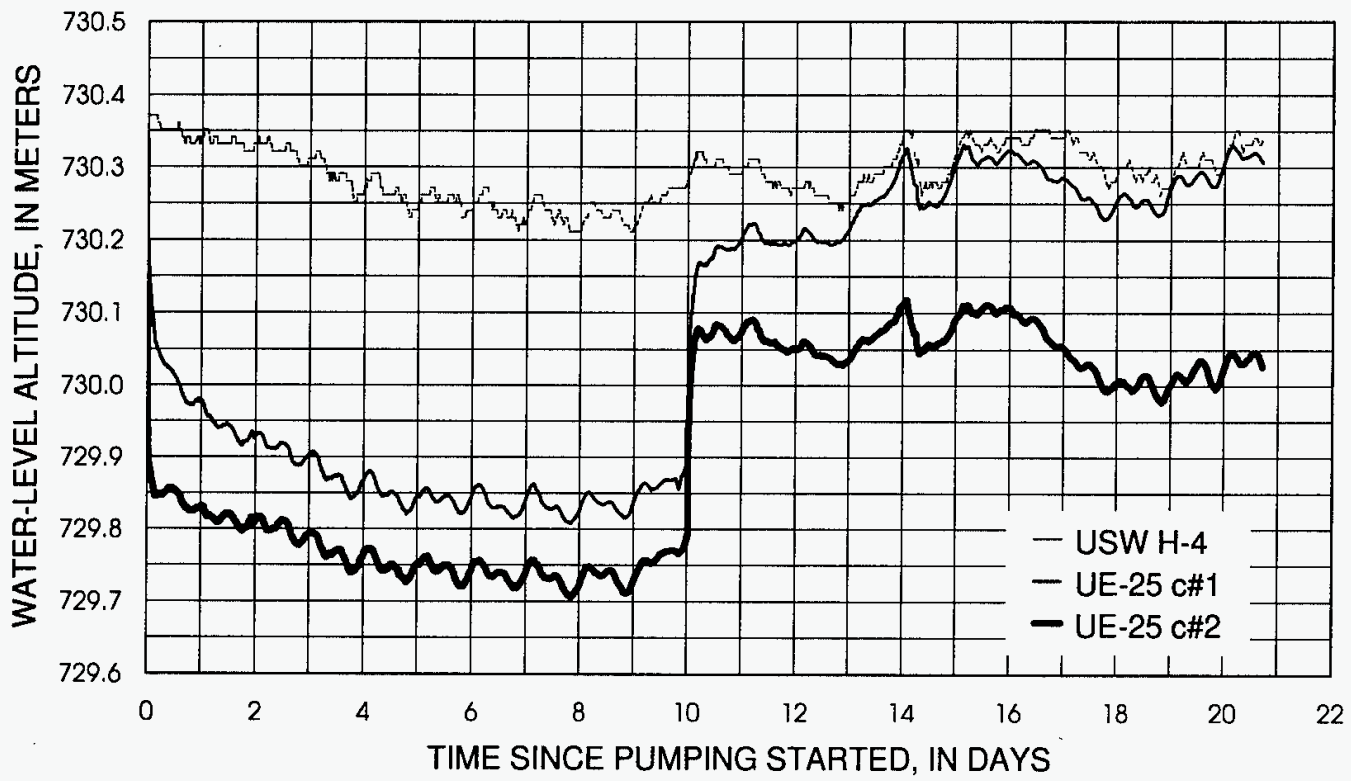

Figure 10. Water-level altitudes in boreholes UE-25 c\#1, UE-25 c\#2, and USW H-4, May-June 1995. 


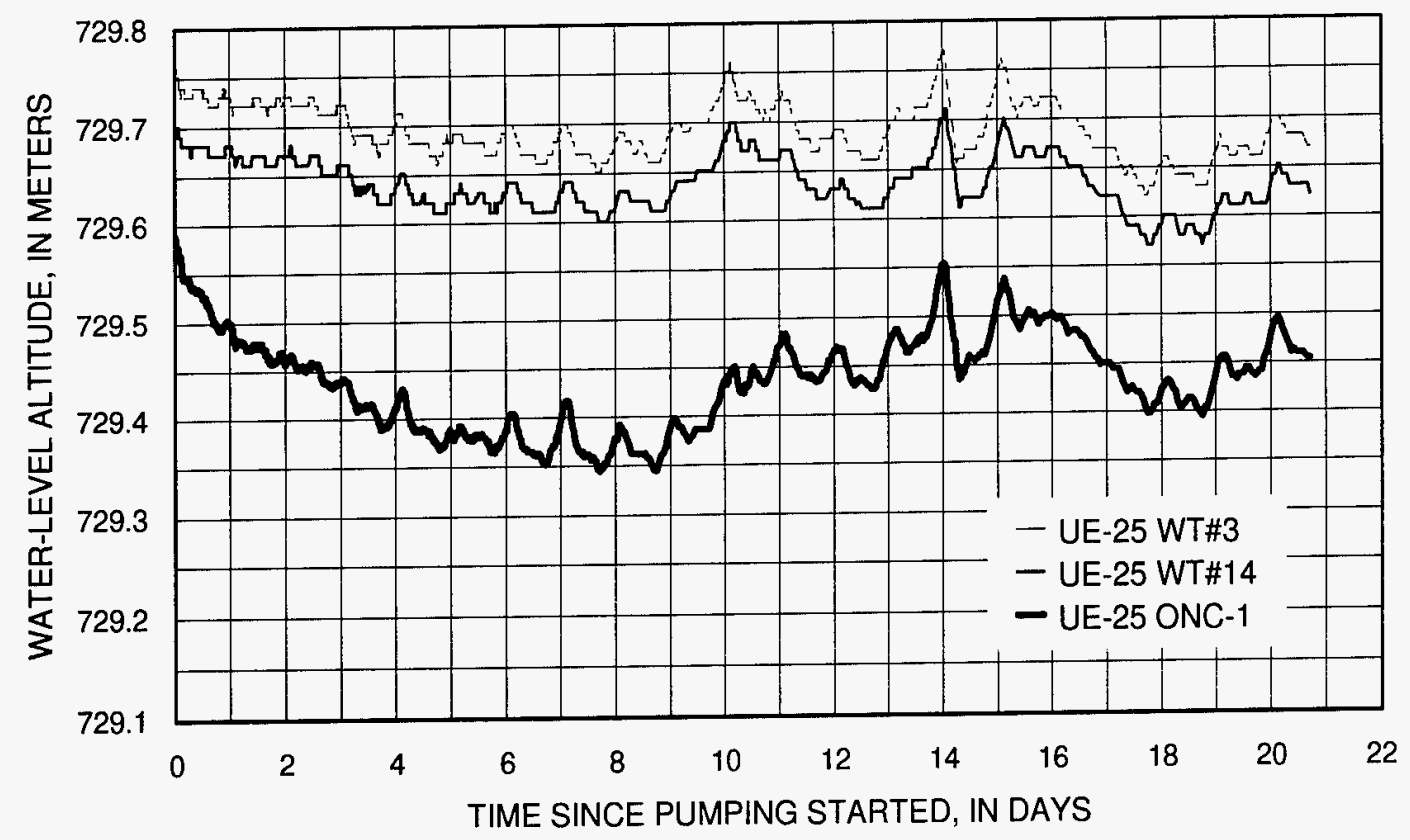

Figure 11. Water-level altitudes in boreholes UE-25 ONC-1, UE-25 WT\#3, and UE-25 WT\#14, MayJune 1995.

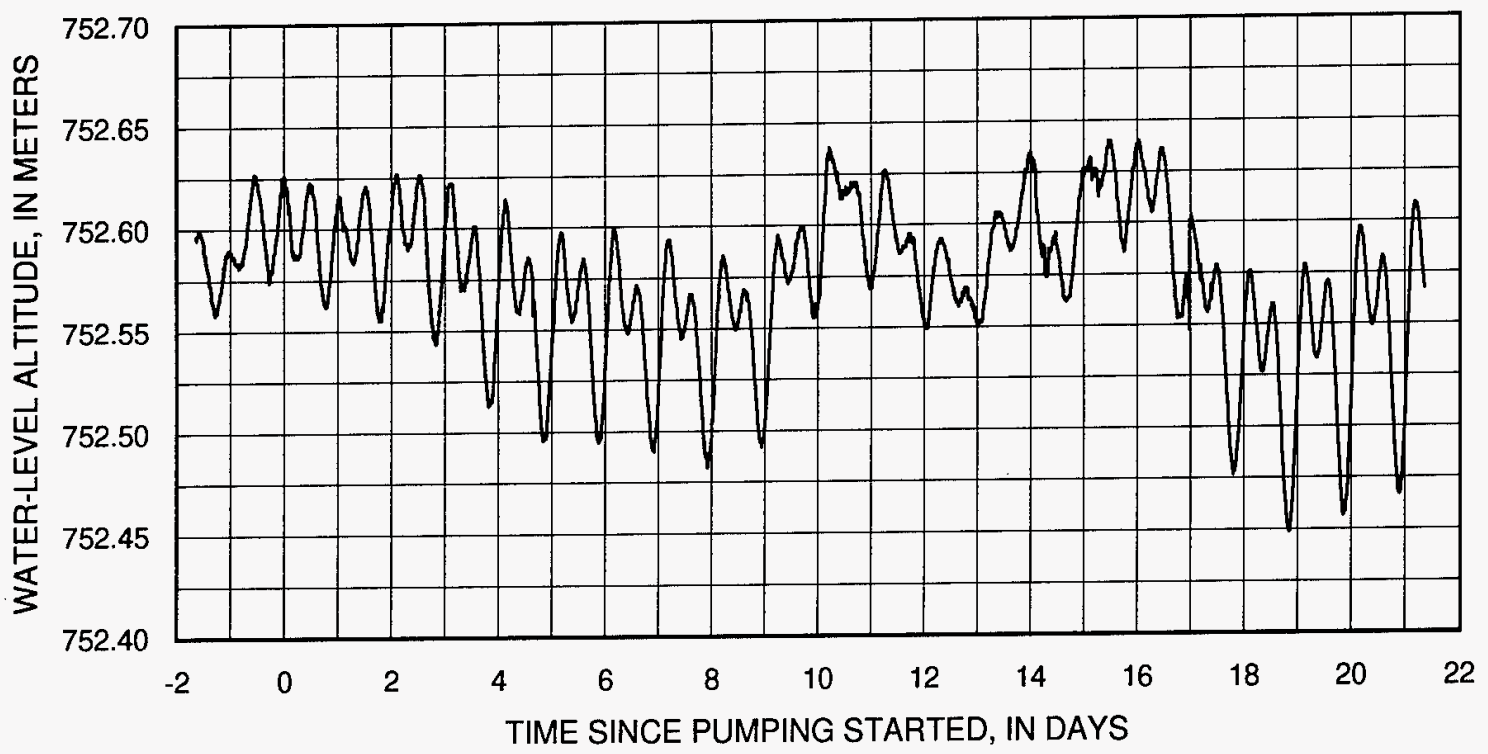

Figure 12. Water-level altitudes in borehole UE-25 p\#1, May-June 1995. 


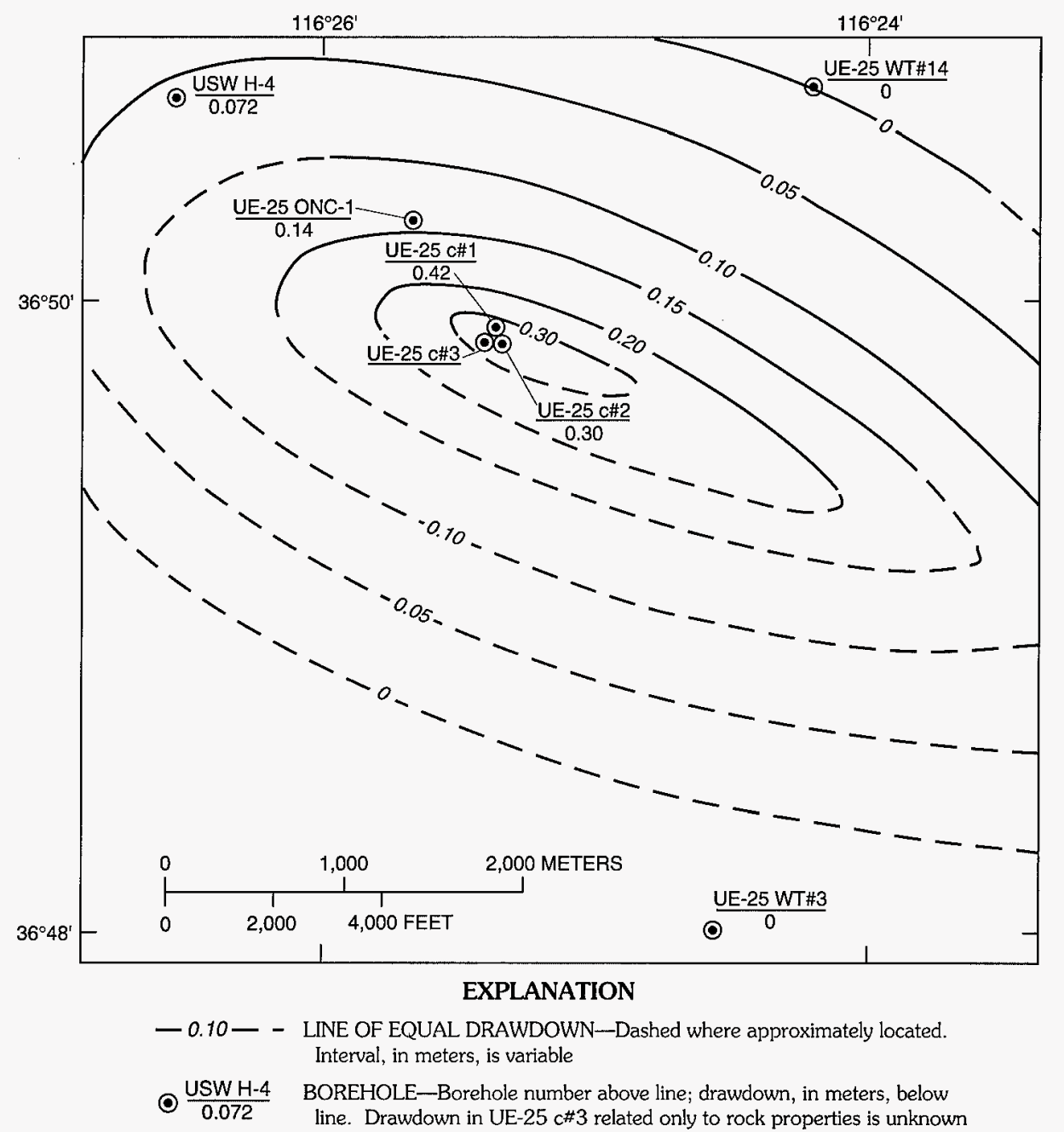

Figure 13. Drawdown in the vicinity of borehole UE-25 c\#3, 14,000 minutes after pumping started, MayðJune 1995.

\section{Borehole UE-25 c\#1}

Located $82.6 \mathrm{~m}$ from the pumping well, borehole UE-25 c\#1 began to exhibit drawdown within 2 minutes of the pump being started (fig. 15). Drawdown became relatively constant at $0.32-0.34 \mathrm{~m}$ between 900 and 1,600 minutes after pumping started. After 1,600 minutes, drawdown resumed at a progressively decreasing rate and was $0.43 \mathrm{~m}$ when the pump was turned off, 14,403 minutes after pumping started. Complete recovery from pumping occurred about 11,400 minutes after pumping stopped, but a distinct slowing of the recovery occurred between 950 and 1,500 minutes after the pump was turned off (fig. 16).

Drawdown and recovery in borehole UE-25 c\#1 were characteristic of an unconfined aquifer and were analyzed by the method of Neuman (1975). Matched to the type curve for $\beta=0.004$ (fig. 15), the drawdown data from borehole UE-25 $\mathrm{c \# 1}$ indicated the following:

$$
\begin{aligned}
& T=\frac{17.9 \mathrm{~L} / \mathrm{s} \times 86.4 \mathrm{~m}^{3} / \mathrm{d} \times 1}{4 \times \pi \times 0.075 \mathrm{~m} \times 1 \mathrm{~L} / \mathrm{s}}=1,641.0=1,600 \mathrm{~m}^{2} / d \\
& K_{r}=\frac{1,641 \mathrm{~m}^{2} / d}{251.8 \mathrm{~m}}=6.52=6.5 \mathrm{~m} / d \\
& K_{z}=\frac{6.52 \mathrm{~m} / \mathrm{d} \times 0.004 \times(251.8 \mathrm{~m})^{2}}{(82.6 \mathrm{~m})^{2}}=0.24=0.2 \mathrm{~m} / d \\
& S=\frac{4 \times 1,641.0 \mathrm{~m}^{2} / \mathrm{d} \times 2.0 \mathrm{~min} \times 1}{1,440 \mathrm{~min} / \mathrm{d} \times(82.6 \mathrm{~m})^{2}}=0.001 \\
& S_{y}=\frac{4 \times 1,641.0 \mathrm{~m}^{2} / d \times 15.5 \mathrm{~min} \times 1}{1,440 \mathrm{~min} / \mathrm{d} \times(82.6 \mathrm{~m})^{2}}=0.010=0.01
\end{aligned}
$$




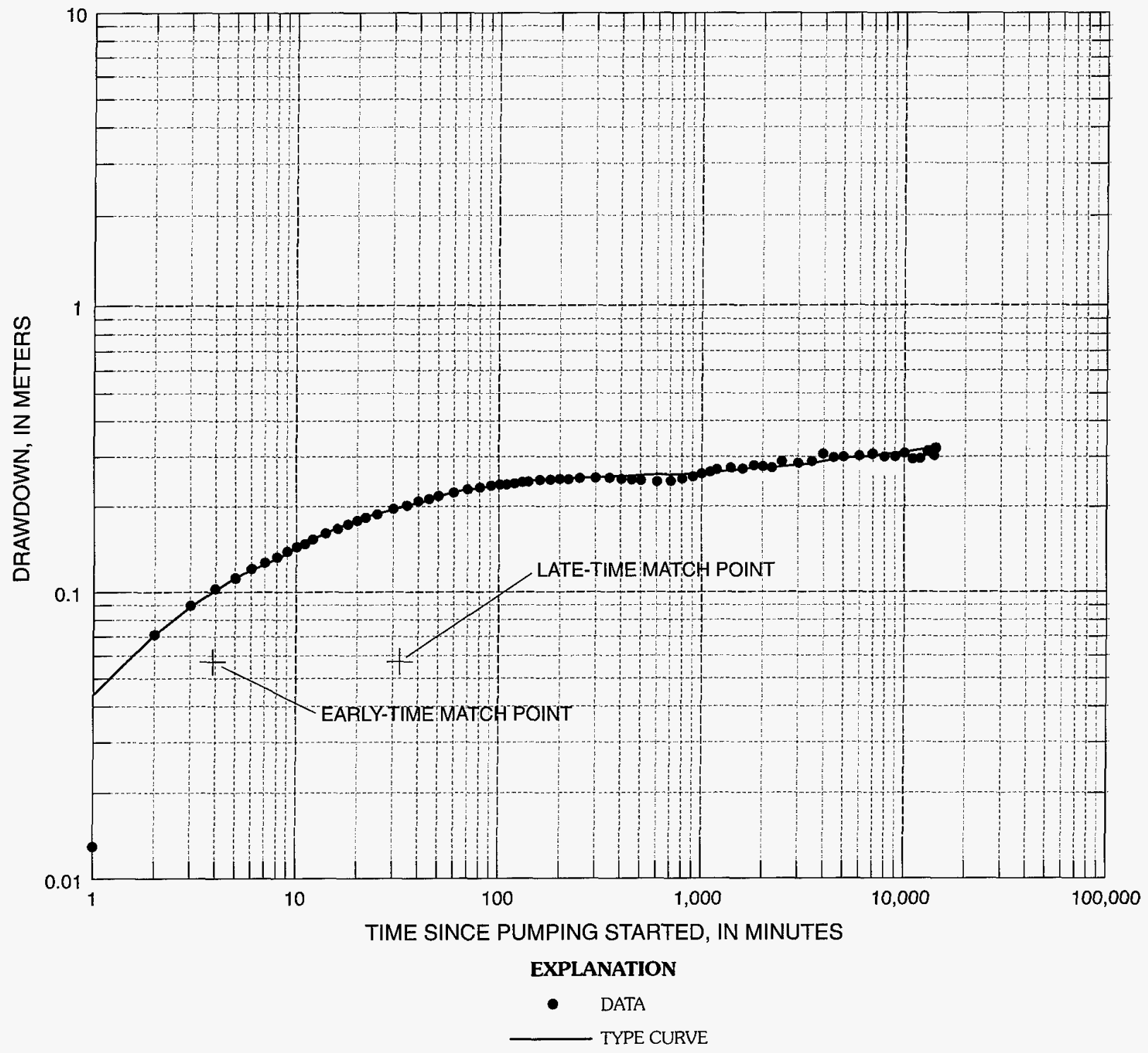

Figure 14. Analysis of drawdown in borehole UE-25 c\#2, May-June 1995. 


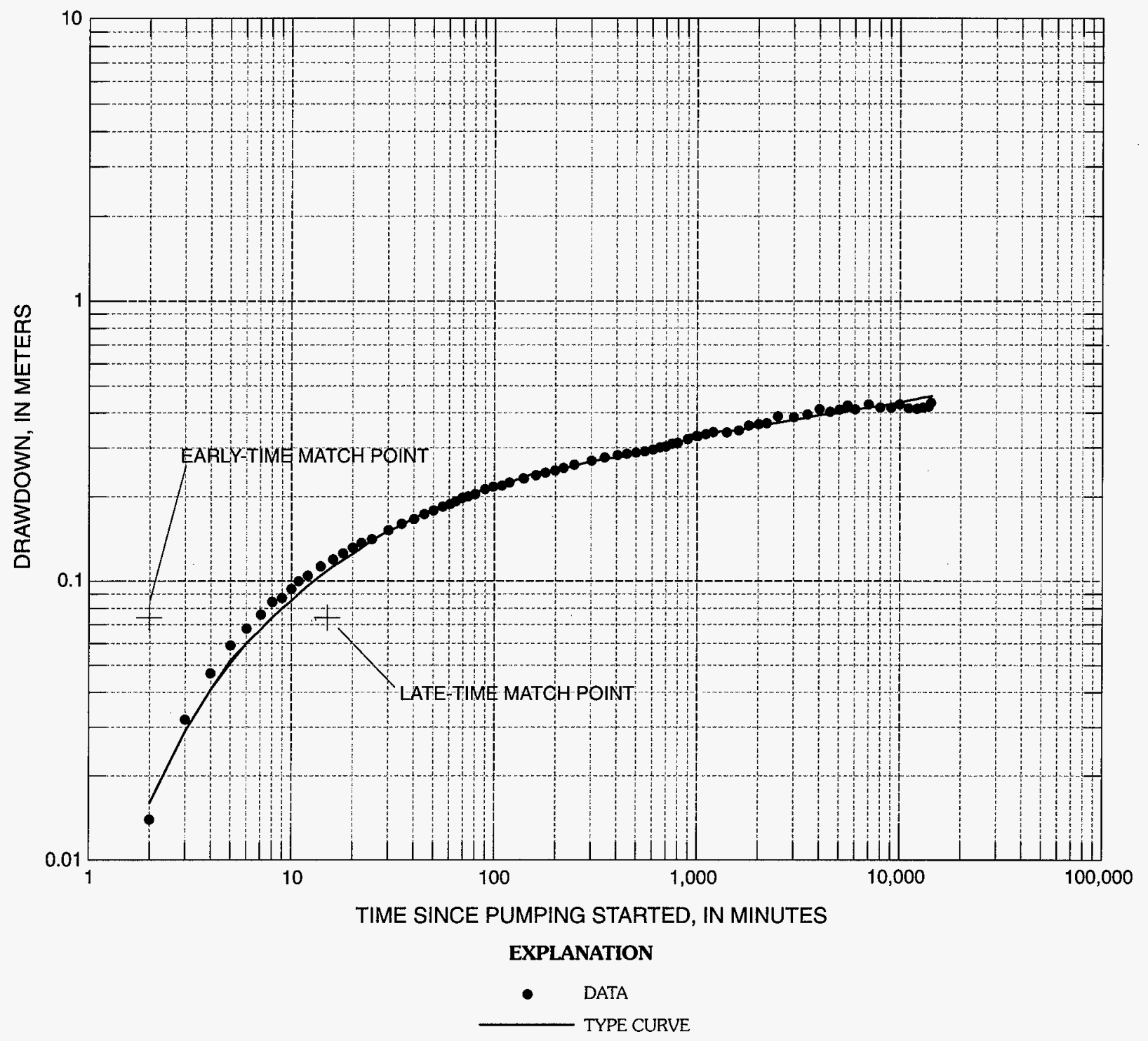

Figure 15. Analysis of drawdown in borehole UE-25 c\#1, May-June 1995. 


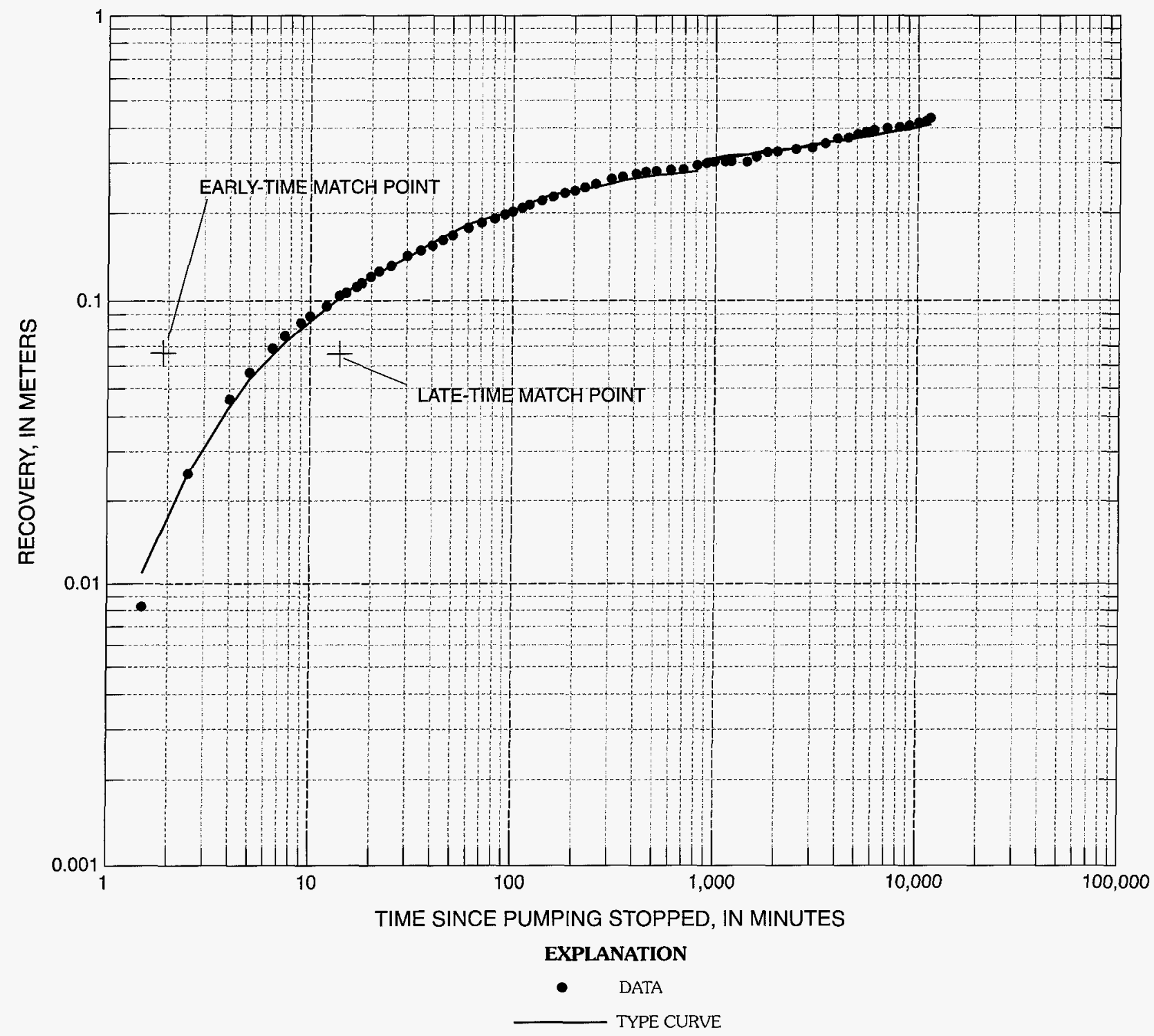

Figure 16. Analysis of recovery in borehole UE-25 c\#1, May-June 1995. 
Matched to the type curve for $\beta=0.004$

(fig. 16), the recovery data from borehole UE-25 c\#1 indicated the following:

$$
\begin{aligned}
& T=\frac{17.9 \mathrm{~L} / \mathrm{s} \times 86.4 \mathrm{~m}^{3} / \mathrm{d} \times 1}{4 \times \pi \times 0.067 \mathrm{~m} \times 1 \mathrm{~L} / \mathrm{s}}=1,836.9=1,800 \mathrm{~m}^{2} / d \\
& K_{r}=\frac{1,836.9 \mathrm{~m}^{2} / \mathrm{d}}{251.8 \mathrm{~m}}=7.30=7.3 \mathrm{~m} / \mathrm{d}
\end{aligned}
$$$$
K_{z}=\frac{7.30 \mathrm{~m} / \mathrm{d} \times 0.004 \times(251.8 \mathrm{~m})^{2}}{(82.6 \mathrm{~m})^{2}}=0.27=0.3 \mathrm{~m} / \mathrm{d}
$$$$
S=\frac{4 \times 1,836.9 \mathrm{~m}^{2} / \mathrm{d} \times 1.8 \mathrm{~min} \times 1}{1,440 \mathrm{~min} / \mathrm{d} \times(82.6 \mathrm{~m})^{2}}=0.001
$$$$
S_{y}=\frac{4 \times 1,836.9 \mathrm{~m}^{2} / \mathrm{d} \times 14 \mathrm{~min} \times 1}{1,440 \mathrm{~min} / \text { day } \times(82.6 \mathrm{~m})^{2}}=0.010=0.01
$$

\section{Borehole UE-25 ONC-1}

Located $842.8 \mathrm{~m}$ from the pumping well, borehole UE-25 ONC-1 did not begin to exhibit drawdown until 110 minutes after pumping started. Drawdown

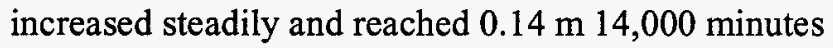
after pumping started (fig. 17). Recovery was detectable 140 minutes after pumping stopped, became constant at about $0.085 \mathrm{~m}$ between 3,800 and 10,000 minutes after pumping stopped, resumed increasing thereafter, and apparently was complete about 14,800 minutes after pumping stopped.

The erratic recovery was not analyzable, but the drawdown was characteristic of an infinite, homogeneous, isotropic, confined aquifer and was analyzed by the method of Theis (1935). The relevant equations are:

$$
\begin{gathered}
T=\frac{Q \times W(\mu)}{4 \pi s} \\
K_{r}=T / b
\end{gathered}
$$

$$
S=\frac{4 T t \mu}{r^{2}}
$$

where $W(\mu)=$ well function for an infinite, homogeneous, isotropic, confined aquifer;

$s=$ drawdown, in meters, corresponding to $W(\mu)$;

$\mu=\mathrm{a}$ dimensionless parameter defined by equation 9 ;

$t=$ time, in days, corresponding to $\mu$; and all other variables are as defined for equations 2-6.

Matched to the type curve for the above analytical method (fig. 17), the drawdown data from borehole UE-25 ONC-1 indicated the following:

$$
\begin{aligned}
& T=\frac{17.9 \mathrm{~L} / \mathrm{s} \times 86.4 \mathrm{~m}^{3} / \mathrm{d} \times 1}{4 \times \pi \times 0.043 \mathrm{~m} \times 1 \mathrm{~L} / \mathrm{s}}=2,862.1=2,900 \mathrm{~m}^{2} / d \\
& S=\frac{4 \times 2,862.1 \mathrm{~m}^{2} / d \times 240 \mathrm{~min} \times 1}{1,440 \mathrm{~min} / \mathrm{d} \times(842.8 \mathrm{~m})^{2}}=0.003
\end{aligned}
$$

Hydraulic conductivity could not be calculated from the drawdown data, because the thickness of transmissive rock connecting borehole UE-25 ONC-1 to the pumping well was unknown.

\section{Borehole USW H-4}

Located $2,245.2 \mathrm{~m}$ from the pumping well, borehole USW H-4 was not expected to show a response to pumping in borehole UE-25 $\mathrm{c} \# 3$ because of numerous faults between the two boreholes. However, after filtering water-level altitudes to remove Earth-tide effects and applying a correction for barometric effects, drawdown and recovery in USW H-4 in response to pumping clearly were evident.

Pumping-induced drawdown in borehole USW $\mathrm{H}-4$ began to occur about 15 minutes after pumping started. After 14,000 minutes, this drawdown reached $0.072 \mathrm{~m}$. Recovery from pumping was detectable 15 minutes after pumping and was complete 9,700 minutes after pumping stopped. Because recovery was erratic, the recovery data were not analyzable. 


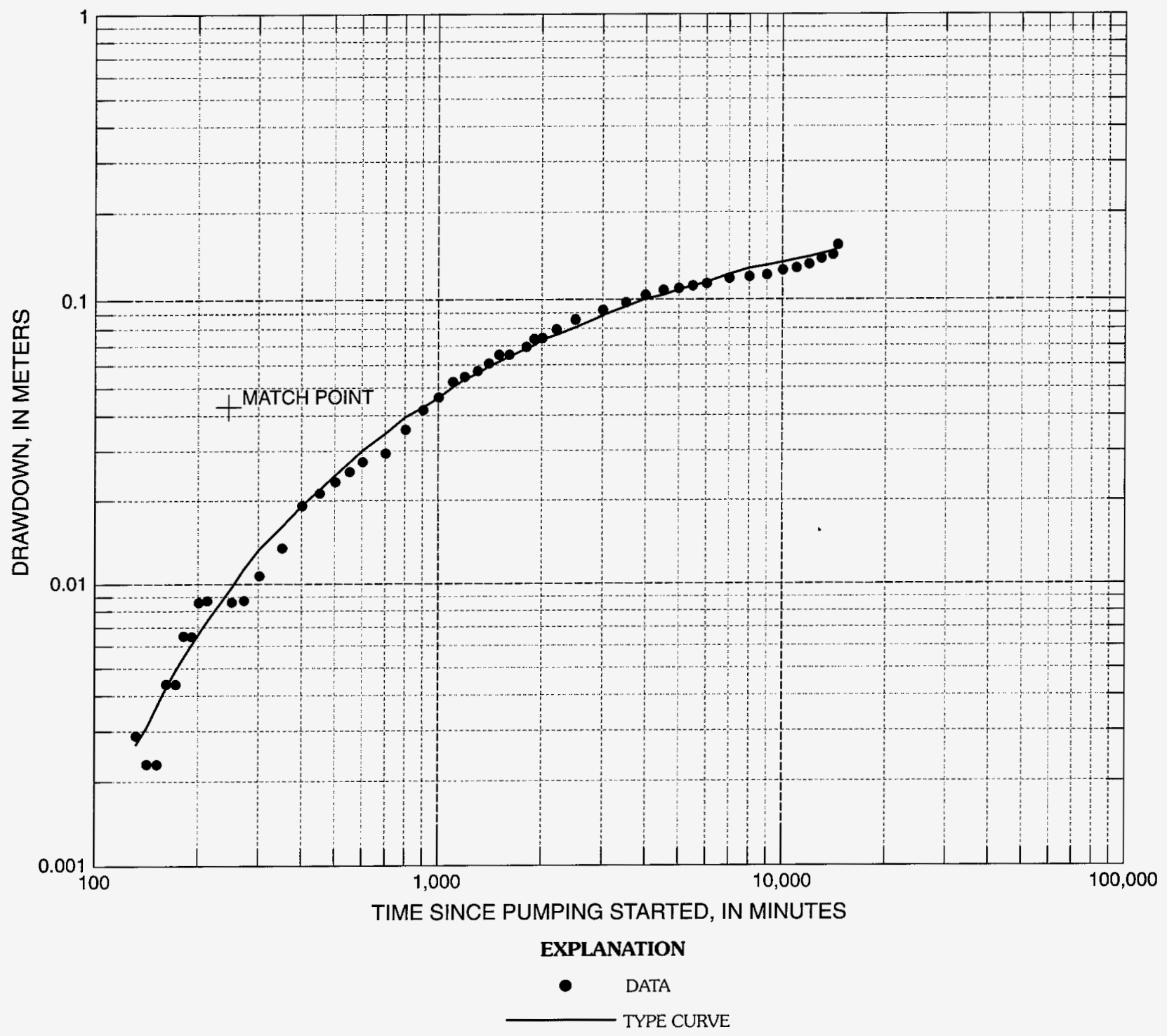

Figure 17. Analysis of drawdown in borehole UE-25 ONC-1, May-June 1995. 
Drawdown in borehole USW $\mathrm{H}-4$ showed the combined effects of borehole storage release and pumping-induced aquifer stress. During the first 550 minutes after pumping started, the drawdown data, plotted as a function of time on log-log paper, fit a straight line with a slope of approximately $45^{\circ}$ (fig. 18), which indicates a release of water from borehole storage. From 550 to about 1,200 minutes after pumping started, the drawdown data conformed to a straight line representing a transition from borehole storage release to release of water from the aquifer. After 1,200 minutes of pumping, the drawdown data conformed roughly to the type curve of Theis (1935) for an infinite, homogeneous, isotropic, confined aquifer (fig. 18).

Analyzed by the method of Theis (1935), the late-time drawdown data indicated the following:

$$
T=\frac{17.9 L / s \times 86.4 m^{3} / d \times 1}{4 \times \pi \times 0.038 m \times 1 L / s}=3,238.7=3,200 m^{2} / d
$$$$
K_{r}=\frac{3,238.7 m^{2} / d}{276.4 m}=11.7=12 \mathrm{~m} / d
$$

$$
S=\frac{4 \times 3,238.7 \mathrm{~m}^{2} / d \times 1,400 \mathrm{~min} \times 1}{1,440 \mathrm{~min} / d \times(2,245.2 \mathrm{~m})^{2}}=0.002
$$

\section{Boreholes UE-25 WT\#14 and UE-25 WT\#3}

After filtering water-level altitudes to remove Earth-tide effects and applying a correction to changes in the filtered data to remove barometric effects, erratic water-level changes of less than $0.057 \mathrm{~m}$ remained in the data obtained from boreholes UE-25 WT\#14 and UE-25 WT\#3 during and after the pumping in borehole UE-25 c\#3 (fig. 19). These erratic water-level changes are attributed to imprecision in the instrumentation and methods of computation. Pumping borehole UE-25 $\mathrm{c \# 3}$ produced no detectable response in borehole UE-25 WT\#14, $2,249.1 \mathrm{~m}$ from the pumping well, and in borehole UE-25 WT\#3, 3,525.6 $\mathrm{m}$ from the pumping well.

\section{Drawdown as a Function of Distance}

For an infinite, homogeneous, isotropic, confined aquifer, values of drawdown in observation wells plotted at any time since the start of pumping as a function of the log of distance from the pumping well should fall on a straight line (Cooper and Jacob, 1946). The equations used to compute hydrologic properties by this analytical method are:

$$
\begin{gathered}
T=\frac{2.3 Q}{2 \pi \Delta s_{d}} \\
S=\frac{2.25 T t}{r_{o}^{2}}
\end{gathered}
$$

where $\Delta s_{d}=$ drawdown, in meters, over 1 log cycle of distance;

$\mathrm{t}=$ time, in days;

$\mathrm{r}_{\mathrm{o}}=$ distance, in meters, from the pumping well at zero drawdown; and all other variables are as defined for equations 2-6.

After 14,000 minutes of pumping, drawdown values for boreholes UE-25 c\#1 $(0.42 \mathrm{~m}), \mathrm{UE}-25$ ONC-1 $(0.14 \mathrm{~m})$, and USW H-4 $(0.072 \mathrm{~m})$ plotted on a straight line (fig. 20). The drawdown in borehole UE-25 c\#2 $(0.30 \mathrm{~m})$ was about $0.23 \mathrm{~m}$ less than anticipated from the equation of the regression line fit through the other data points shown in figure 20. Analyzed by the method of Cooper and Jacob (1946), the drawdown in boreholes UE-25 c\#1, UE-25 ONC-1, and USW H-4 indicated the following:

$$
\begin{aligned}
& T=\frac{2.3 \times 17.9 \mathrm{~L} / \mathrm{s} \times 86.4 \mathrm{~m}^{3} / \mathrm{d}}{2 \times \pi \times 0.2482 \mathrm{~m} \times 1 \mathrm{~L} / \mathrm{s}}=2,280.9=2,300 \mathrm{~m}^{2} / d \\
& S=\frac{2.25 \times 2,280.9 \mathrm{~m}^{2} / \mathrm{d} \times 14,000 \mathrm{~min}}{1,440 \mathrm{~min} / \mathrm{d} \times(3,864.25 \mathrm{~m})^{2}}=0.003
\end{aligned}
$$

The smaller-than-anticipated drawdown in borehole UE-25 c\#2 indicates that different geologic features might be affecting drawdown in UE-25 c\#2 than in other monitored boreholes. It is possible that the northerly trending Midway Valley or Paintbrush 


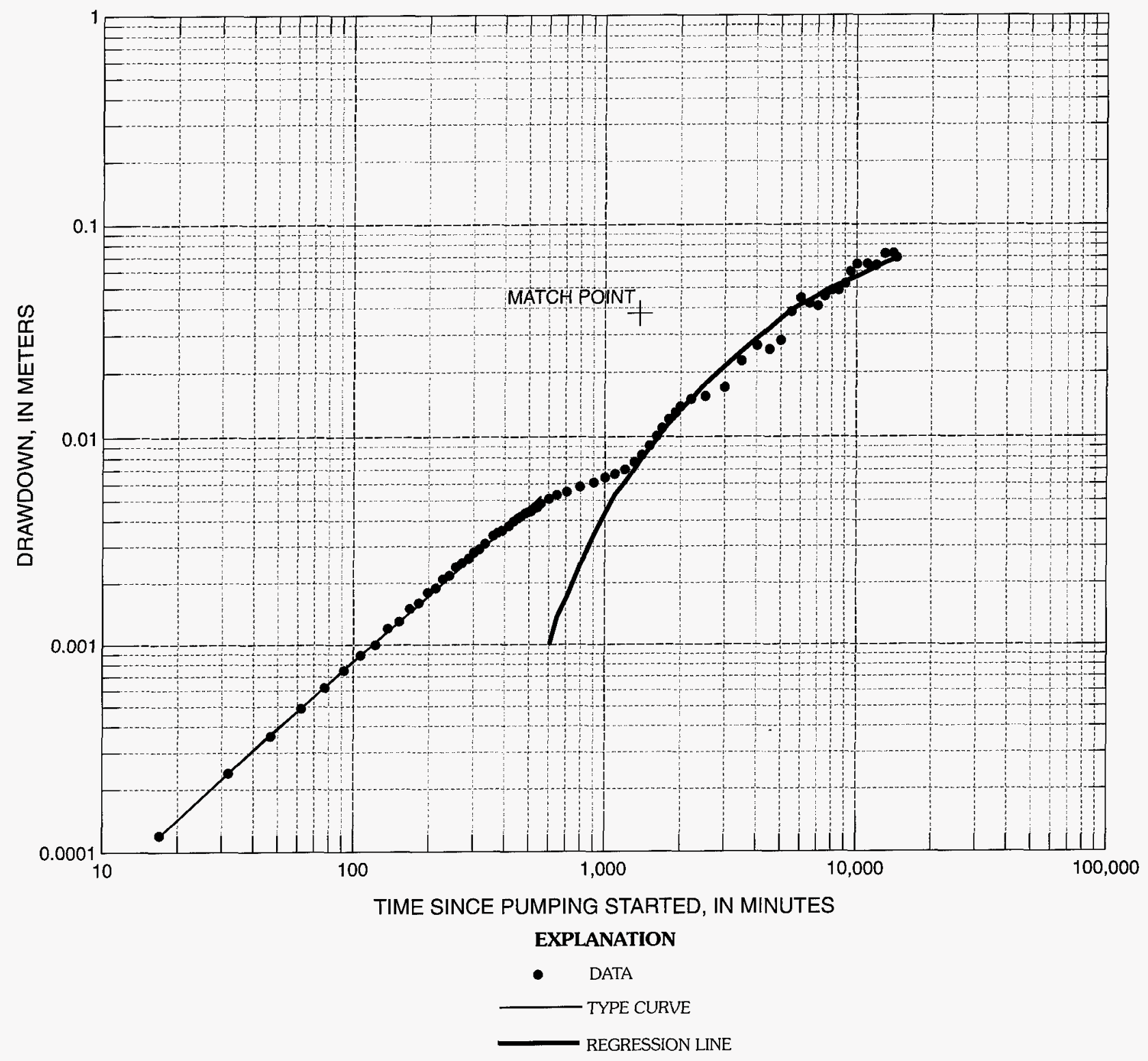

Figure 18. Analysis of drawdown in borehole USW H-4, May-June 1995. 
UE-25 WT\#14

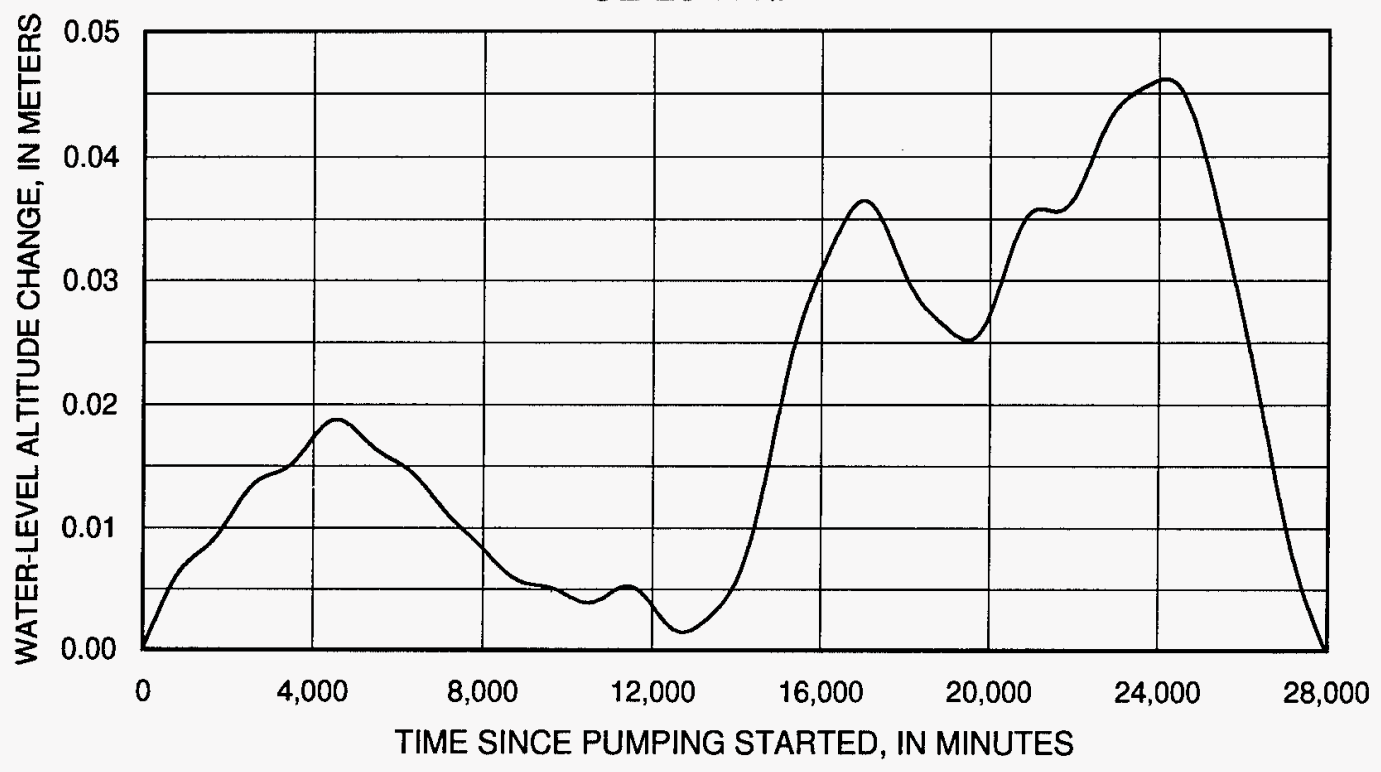

UE-25 WT\#3

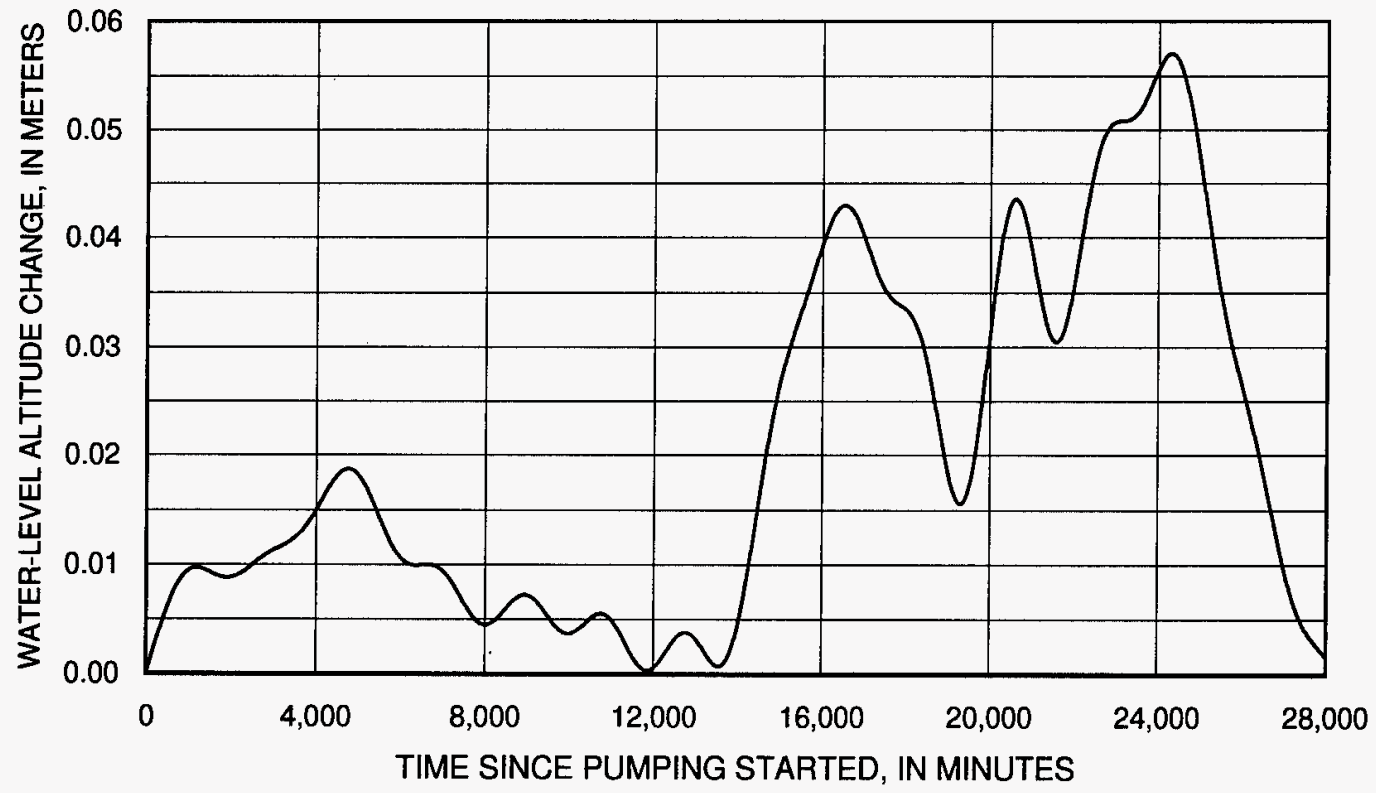

Figure 19. Residual changes in water-level altitudes in boreholes UE-25 WT\#14 and UE-25 WT\#3 after applying corrections for Earth-tide and barometric effects, May-June 1995. Pumping ceased after 14,403 minutes. Fluctuations are considered artifacts of measuring and computational precision. 


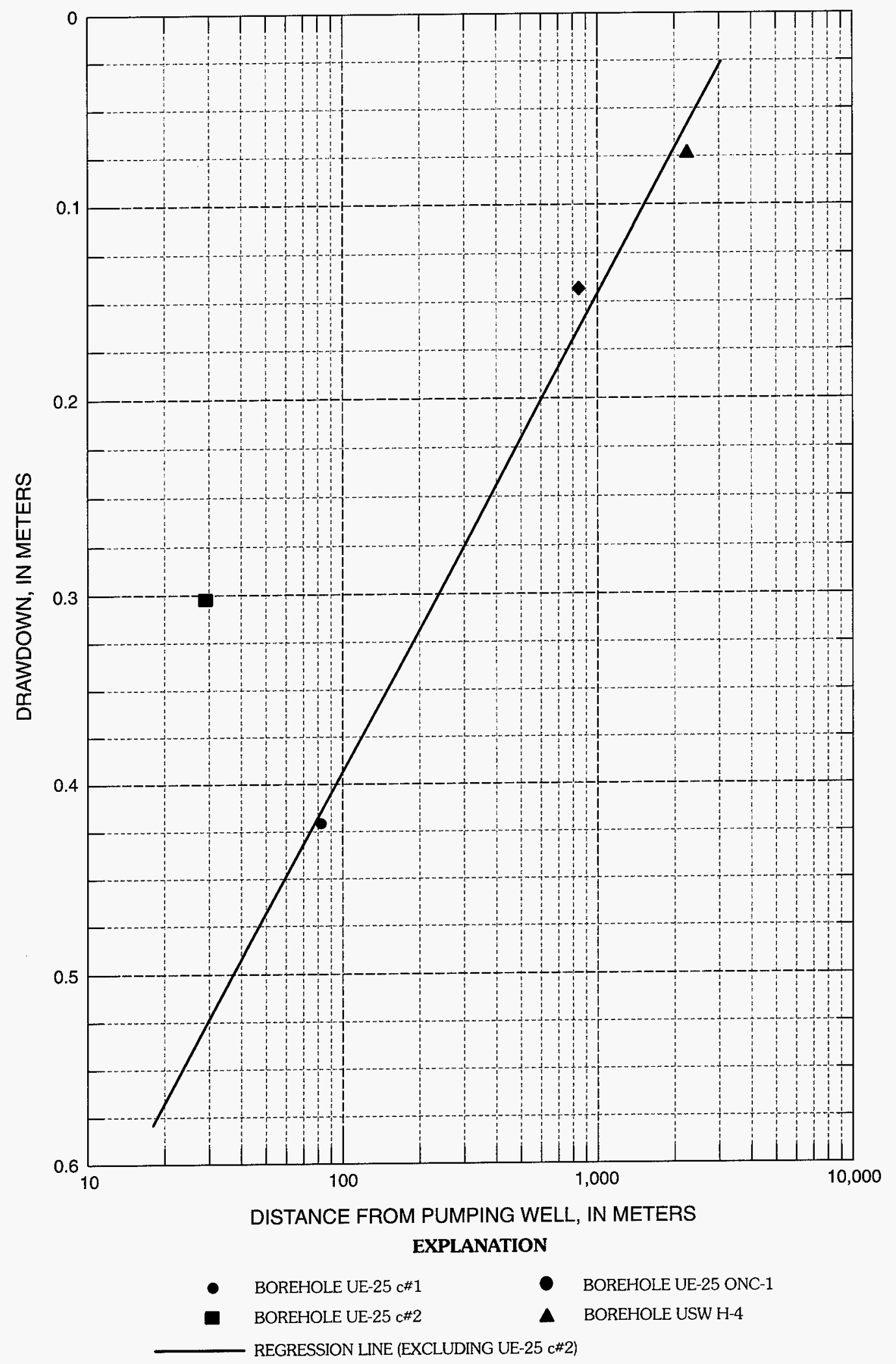

Figure 20. Analysis of drawdown in observation wells as a function of distance from the pumping well after 14,000 minutes of pumping, May-June 1995. 
Table 4. Summary of hydrologic properties computed from drawdown or recovery with time in observation wells, pumping test in borehole UE-25 c\#3, May-June 1995

[nd, no data]

\begin{tabular}{|c|c|c|c|c|c|}
\hline \multirow{2}{*}{ Hydrologic property } & \multirow{2}{*}{$\begin{array}{c}\text { UE-25 c\#2 } \\
\text { Drawdown }\end{array}$} & \multicolumn{2}{|c|}{ UE-25 c\#1 } & \multirow{2}{*}{$\begin{array}{c}\text { UE-25 ONC-1 } \\
\text { Drawdown }\end{array}$} & \multirow{2}{*}{$\frac{\text { USW H-4 }}{\text { Drawdown }}$} \\
\hline & & Drawdown & Recovery & & \\
\hline Aquifer type & Unconfined & Unconfined & Unconfined & Confined & Confined \\
\hline Transmissivity $\left(\mathrm{m}^{2} / \mathrm{d}\right)$ & 2,100 & 1,600 & 1,800 & 2,900 & 3,200 \\
\hline Horizontal hydraulic conductivity $(\mathrm{m} / \mathrm{d})$ & 13 & 6.5 & 7.3 & nd & 12 \\
\hline Vertical hydraulic conductivity (m/d) & 1.7 & 0.2 & 0.3 & nd & nd \\
\hline Storativity & 0.003 & 0.001 & 0.001 & 0.003 & 0.002 \\
\hline Specific yield & 0.2 & 0.01 & 0.01 & nd & nd \\
\hline
\end{tabular}

Table 5. Summary of hydrologic properties determined from aquifer tests at the C-hole complex in 1984 and 1995

[1984 test results from Geldon, 1996; nd, no data]

\begin{tabular}{lccccc}
\hline & & 1984 & & 1995 \\
\cline { 2 - 4 } & Hydrologic property & UE-25 c\#1 & UE-25 c\#2 & UE-25 c\#3 & All boreholes \\
\hline Aquifer test & Pumping & Pumping & Injection & Pumping \\
Transmissivity $\left(\mathrm{m}^{2} / \mathrm{d}\right)$ & 1,800 & 2,200 & 3,200 & $1,600-3,200$ \\
Horizontal hydraulic conductivity $(\mathrm{m} / \mathrm{d})$ & 9.1 & 13 & 12 & $6.5-13$ \\
Vertical hydraulic conductivity $(\mathrm{m} / \mathrm{d})$ & 0.6 & 1.7 & nd & $0.2-1.7$ \\
Storativity & 0.004 & 0.004 & 0.002 & $0.001-0.003$ \\
Specific yield & $>0.007$ & 0.07 & nd & $0.01-0.2$ \\
\hline
\end{tabular}

Canyon Fault might be affecting drawdown more in UE-25 $\mathrm{c} \# 2$ than in other boreholes, whereas the northwesterly trending zone of discontinuous faults between Bow Ridge and Antler Wash might be affecting drawdown in UE-25 c\#1, UE-25 ONC-1, and USW H-4 more than in UE-25 c\#2. Despite localscale heterogeneity, figure 13 indicates less drawdown with respect to distance from the pumping well, UE-25 c\#3, in a northwesterly direction than in a northeasterly direction. Because transmissivity is inversely proportional to the ratio of drawdown to distance from the pumping well, figure 13 indicates that transmissivity within a $3.5-\mathrm{km}$ radius of borehole UE-25 $\mathrm{c \# 3}$ generally should be largest in alinement with the zone of northwesterly trending faults between Bow Ridge and Antler Wash and smallest perpendicular to this fault zone. Cross-hole hydraulic tests at multiple sites, combined with numerical modeling, probably are needed to establish the range in magnitude and directional aspects of hydrologic properties at the scale of Yucca Mountain.
Results obtained from the analysis of drawdown as a function of distance are consistent with results obtained by analyzing drawdown or recovery as a function of time in individual boreholes. Hydrologic properties obtained from analyses of drawdown or recovery with time are summarized in table 4 .

\section{Comparison Between 1984 and 1995 Aquifer-Test Results}

As indicated in table 5, values of transmissivity, hydraulic conductivity, storativity, and specific yield computed from three pumping tests and a constantflux injection test conducted in the C-holes during 1984 compare favorably with values of hydrologic properties determined from the pumping test conducted in borehole UE-25 c\#3 from May to June 1995. Results of the 1984 aquifer tests, thus, are verified by the 1995 aquifer test. 


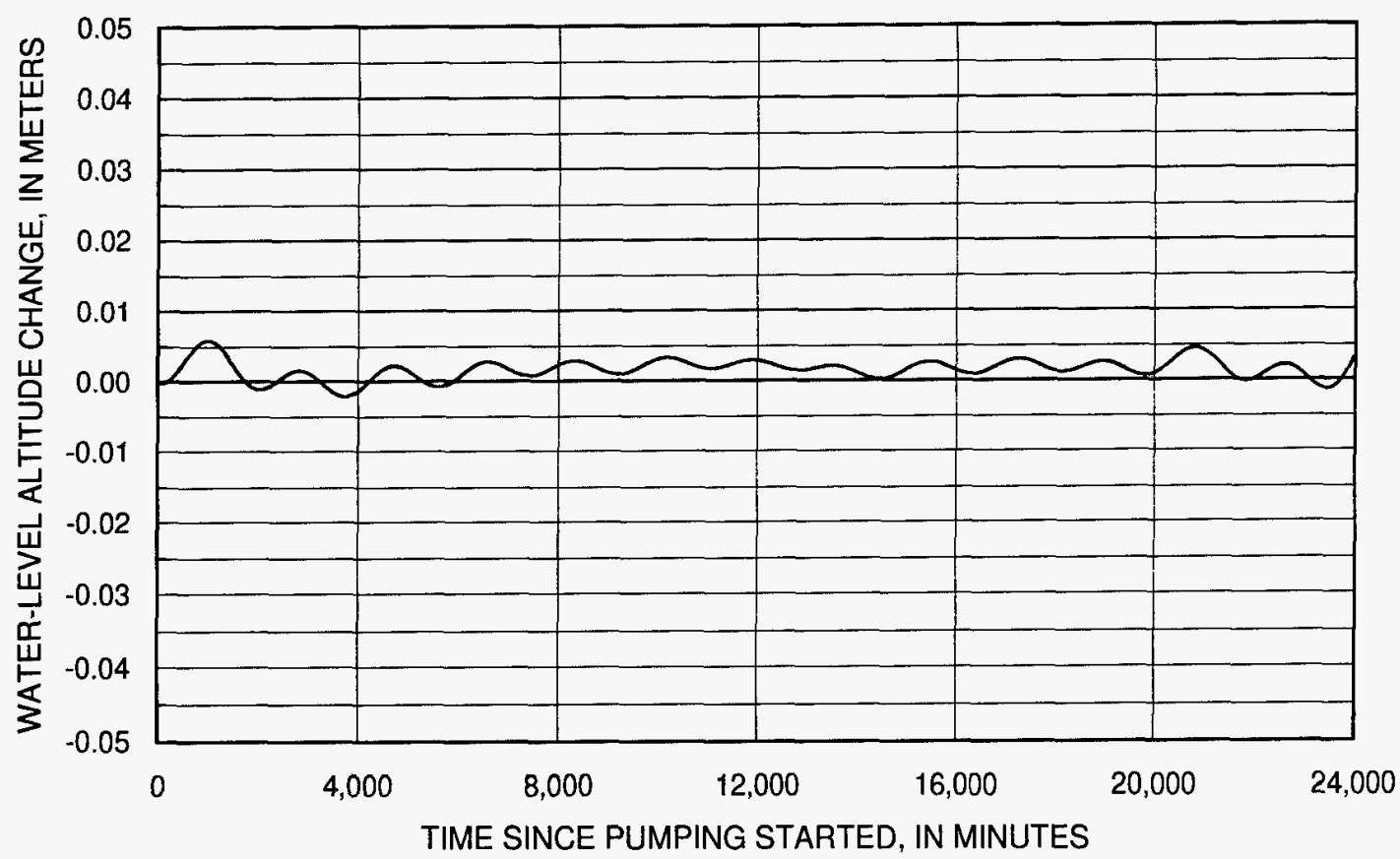

Figure 21. Residual changes in water-level altitudes in borehole UE-25 p\#1 after applying corrections for Earth-tide and barometric effects, May-June 1995. Pumping ceased after 14,403 minutes. No response to pumping was detected.

\section{HYDRAULIC CONNECTION BETWEEN MIOCENE AND PALEOZOIC ROCKS}

Borehole UE-25 p\#1, which is completed in Paleozoic carbonate rocks was monitored during the 1984 and 1995 pumping tests at the C-hole complex to determine if the Miocene tuffaceous rocks are connected hydraulically to the Paleozoic carbonate rocks. Although Geldon (1996) reported $0.58 \mathrm{~m}$ of drawdown in borehole UE-25 p\#1 during a 6.7-day pumping test in borehole UE-25 c\#2 in March 1984, no drawdown in borehole UE-25 p\#1 was observed during a 9.5-day pumping test in borehole UE-25 $\mathrm{c \# 3}$ in May 1984 or during the pumping test described in this report (fig. 21). In retrospect, the apparent drawdown in borehole UE-25 $\mathrm{p} \# 1$ during the pumping test in March 1984 could have resulted from a mechanical problem, such as transducer drift.

The absence of drawdown in borehole UE-25 $\mathrm{p} \# 1$ in response to pumping the $\mathrm{C}$-holes should not be interpreted as indisputable evidence that the Miocene tuffaceous rocks are isolated hydraulically from the Paleozoic carbonate rocks. A flux of water from the lower to the upper aquifer could be sustained during a pumping test at the $\mathrm{C}$-hole complex at rates of
$13-25 \mathrm{~L} / \mathrm{s}$ for $7-15$ days without lowering the potentiometric surface of the lower aquifer if the volume of water stored in the Paleozoic carbonate rocks is extremely large. The extent of hydraulic connection between the Miocene tuffaceous rocks and the Paleozoic carbonate rocks might be established by numerical modeling of the C-hole area or by monitoring changes in the chemistry of water sampled from the $\mathrm{C}$-holes as pumping tests progress. Both types of studies are in progress.

\section{SUMMARY AND CONCLUSIONS}

A multiple-well interference (pumping) test was conducted in Miocene tuffaceous rocks at the C-hole complex at Yucca Mountain, Nev., from May 22 to June 12,1995 . The test was conducted (1) to determine hydrologic properties of a 486-m-thick section of the Calico Hills Formation and Crater Flat Group; (2) to verify results of aquifer tests conducted in 1984 at the C-hole complex; and (3) to provide constraints with which to assess the accuracy of planned pumping tests in specific intervals of the C-holes. 
During the pumping test, borehole UE-25 $\mathrm{c} \# 3$ was pumped at an average rate of $17.9 \mathrm{~L} / \mathrm{s}$ for 14,403 minutes from May 22 to June 1 . Recovery was monitored from June 1 to June 12. The pumping produced a drawdown of $7.76 \mathrm{~m}$ in UE- $25 \mathrm{c} \# 3,90$ percent of which occurred within 10 minutes of the pump being started. Recovery after the pumping stopped was equally rapid.

As indicated by analyses of aquifer tests conducted in boreholes UE-25 c\#2 and UE-25 c\#3 during 1984, magnitudes of drawdown and recovery in pumping and injection wells at the $\mathrm{C}$-hole complex probably can be attributed to "borehole skin" or frictional head loss. Only the drawdown and recovery measured in observation wells can be used to determine hydrologic properties. During the pumping test in borehole UE-25 c\#3 in 1995, six observation wells completed in the Miocene tuffaceous rocks and one observation well completed in underlying Paleozoic carbonate rocks (a regional aquifer) were monitored.

The six observation wells completed in the Miocene tuffaceous rocks, boreholes UE-25 c\#1, UE-25 c\#2, UE-25 ONC-1, USW H-4, UE-25 WT\#14, and UE-25 WT\#3, are 29.0 to $3,525.6 \mathrm{~m}$ from borehole UE-25 c\#3. Corrected for barometric effects and, where applicable, Earth-tide effects, drawdown in these observation wells ranged from 0 to $0.42 \mathrm{~m}$ after 14,000 minutes of pumping. The spatial distribution of drawdown in the Miocene tuffaceous rocks is interpreted to represent the influence of a northwesterly striking zone of discontinuous faults between Bow Ridge and Antler Wash and, at the scale of the C-hole complex, the influence of either the Midway Valley or Paintbrush Canyon Fault.

Responses to pumping in observation wells conformed to two different analytical models. In the two observation wells closest to the pumping well, boreholes UE-25 c\#1 and UE-25 c\#2, drawdown and recovery were characteristic of an unconfined, anisotropic aquifer. The unconfined-aquifer response was observed also during pumping tests conducted in the C-holes in 1984 in the upper intervals of boreholes UE-25 c\#1 and UE-25 c\#2 and in the latter borehole when it was open from the bottom of casing to total depth. The hydrologic character of the uppermost transmissive intervals in the C-holes apparently dominates the response of these boreholes when packers are not emplaced to isolate specific intervals.

In contrast to the C-holes, the responses of boreholes UE-25 ONC-1 and USW H-4 to pumping bore- hole UE-25 c\#3 were characteristic of an infinite, isotropic, homogeneous, confined aquifer. Boreholes UE-25 ONC-1 and USW H-4 apparently were far enough from the pumping well to avoid the influence of locally distributed fractures and gravity drainage from the water table on flow to the pumping well.

Analyses of drawdown or recovery as a function of time in boreholes UE- $25 \mathrm{c \# 1,UE-25} \mathrm{c \# 2,} \mathrm{UE-25}$ ONC-1, and USW H-4 indicated transmissivity values of $1,600-3,200 \mathrm{~m}^{2} / \mathrm{d}$, horizontal hydraulic conductivity values of $6.5-13 \mathrm{~m} / \mathrm{d}$, vertical hydraulic conductivity values of $0.2-1.7 \mathrm{~m} / \mathrm{d}$, storativity values of $0.001-0.003$, and specific yield values of $0.01-0.2$. These results were consistent with an analysis of drawdown in boreholes UE-25 c\#1, UE-25 ONC-1, and USW H-4 as a function of distance after 14,000 minutes of pumping and with the results of aquifer tests conducted in the C-holes in 1984.

Although no drawdown was observed in borehole UE-25 $\mathrm{p} \# 1$ (completed in Paleozoic carbonate rocks) in response to pumping borehole UE-25 c\#3, hydraulic connection between the Miocene tuffaceous rocks and Paleozoic carbonate rocks cannot be refuted by the absence of drawdown. Discharge from the C-holes during a pumping test could be sustained by upward flow from the Paleozoic carbonate rocks without drawing down the potentiometric surface of the deeper aquifer if the volume of water stored in the deeper aquifer is extremely large. Rigorous sampling and analyses of water from the C-holes and other boreholes completed in Miocene tuffaceous rocks and Paleozoic carbonate rocks near the $\mathrm{C}$-holes or numerical flow modeling are needed to resolve whether the Miocene tuffaceous rocks and Paleozoic carbonate rocks in the vicinity of the $\mathrm{C}$-holes are connected hydraulically.

\section{REFERENCES}

Bureau of Reclamation, 1981, Ground water manual: Denver, Colo., $480 \mathrm{p}$.

Carr, M.D., Waddell, S.J., Vick, G.S., Stock, J.M., Monsen, S.A., Harris, A.G., Cork, B.W., and Byers, F.M., Jr., 1986, Geology of drill hole UE-25p \#1-A test hole into pre-Tertiary rocks near Yucca Mountain, southern Nevada: U.S. Geological Survey Open-File Report 86-175, 87 p.

Cooper, H.H., Jr., 1963, Type curves for nonsteady radial flow in an infinite leaky artesian aquifer, in Bentall, Ray, compiler, Shortcuts and special problems in 
aquifer tests: U.S. Geological Survey Water-Supply Paper 1545-C, p. 48-55.

Cooper, H.H., Jr., and Jacob, C.E., 1946, A generalized graphical method for evaluating formation constants and summarizing well-field history: American Geophysical Union Transactions, v. 27, no. 4, p. 526-534.

Day, W.C., Potter, C.J., Sweetkind, D.S., Dickerson, R.P., and San Juan, C.A., in press, Bedrock geologic map of the central block area, Yucca Mountain, Nevada: U.S. Geological Survey Miscellaneous Investigations series Map I-2601, scale 1:6,000.

Frizzell, V.A., Jr., and Shulters, Jacqueline, 1990, Geologic map of the Nevada Test Site, southern Nevada: U.S. Geological Survey Miscellaneous Investigations series Map I-2046, scale 1:100,000.

Galloway, Devin, and Rojstaczer, Stuait, 1988, Analysis of the frequency response of water levels in wells to Earth tides and atmospheric loading, in Hitchon, Brian, and Bachu, Stefan, eds., Proceedings fourth Canadian/ American conference on hydrogeology, fluid flow, heat transfer, and mass transport in fractured rocks: Dublin, Ohio, National Water Well Association, p. 100-113.

Geldon, A.L., 1993, Preliminary hydrogeologic assessment of boreholes UE-25c \#1, UE-25c \#2, and UE-25c \#3, Yucca Mountain, Nevada: U.S. Geological Survey Water-Resources Investigations Report 92-4016, 85 p. 1996, Results and interpretation of preliminary aquifer tests in boreholes UE-25c \#1, UE-25c \#2, and UE-25c \#3, Yucca Mountain, Nye County, Nevada: U.S. Geological Survey Water-Resources Investigations Report 94-4177, 119 p.

Geldon, A.L., Earle, J.D., and Umari, A.M.A., 1997, Determination of barometric efficiency and effective

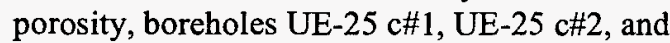
UE-25 c\#3, Yucca Mountain, Nye County, Nevada: U.S. Geological Survey Water-Resources Investigations Report 97-4098, 17 p.

Graves, R.P., Tucci, Patrick, and O'Brien, G.M., 1997, Analysis of water-level data in the Yucca Mountain area, Nevada, 1985-95: U.S. Geological Survey Water-Resources Investigations Report 96-4256, $140 \mathrm{p}$.

Leap, D.I., and Belmonte, P.M., 1992, Influence of pore pressure on apparent dispersivity of a fissured dolomitic aquifer: Dublin, Ohio, Ground Water, v. 30, no. 1, p. 87-95.

Luckey, R.R., Tucci, Patrick, Faunt, C.C., Ervin, E.M., Steinkampf, W.C., D'Agnese, F.A., and Patterson, G.L., 1996, Status of understanding of the saturatedzone ground-water flow system at Yucca Mountain, Nevada, as of 1995: U.S. Geological Survey Water-Resources Investigations Report 96-4077, 71 p.
Neuman, Shlomo, 1975, Analysis of pumping test data from anisotropic unconfined aquifers considering delayed gravity response: American Geophysical Union, Water Resources Research, v. 11, no. 2, p. 329-342.

Nye County Nuclear Waste Repository Project Office, 1995, Borehole UE-25 ONC \#1 and USW NRG-4 drilling and instrumentation report, Yucca Mountain, Nevada: Pahrump, Nev., Nye County Nuclear Waste Repository Program, various paging.

O'Brien, G.M., 1991, Water levels in periodically measured wells in the Yucca Mountain area, Nevada, 1989: U.S. Geological Survey Open-File Report 91-178, 51 p.

O'Brien G.M., Tucci, Patrick, and Burkhardt, D.J., 1995, Water levels in the Yucca Mountain area, Nevada, 1992: U.S. Geological Survey Open-File Report 94-311, $74 \mathrm{p}$.

Plume, R.W., and Carlton, S.M., 1988, Hydrogeology of the Great Basin region of Nevada, Utah, and adjacent States: U.S. Geological Survey Hydrologic Investigations Atlas HA-694-A, scale 1:1,000,000.

Prudic, D.E., Harrill, J.R., and Burbey, T.J., 1993, Conceptual evaluation of regional ground-water flow in the carbonate-rock province of the Great Basin, Nevada, Utah, and adjacent States: U.S. Geological Survey Open-File Report 93-170, 103 p.

Sawyer, D.A., Fleck, R.J., Lanphere, M.A., Warren, R.G., Broxton, D.E., and Hudson, M.R., 1994, Episodic caldera volcanism in the Miocene southwestern Nevada volcanic field: Revised stratigraphic framework, ${ }^{40} \mathrm{Ar} /{ }^{39} \mathrm{Ar}$ geochronology, and implications for magmatism and extension: Boulder, Colo., Geological Society of America Bulletin, v. 106, p. 1304-1318.

Scott, R.B., 1990, Tectonic setting of Yucca Mountain, southwest Nevada, in Wernicke, B.P., ed., Basin and Range extensional tectonics near the latitude of Las Vegas, Nevada: Boulder, Geological Society of America Memoir 176, p. 251-282.

Scott, R.B., and Bonk, Jerry, 1984, Preliminary geologic map of Yucca Mountain, Nye County, Nevada, with geologic sections: U.S. Geological Survey Open-File Report 84-494, scale 1:12,000.

Streeter, V.L., and Wylie, E.B., 1975, Fluid mechanics, Sixth ed.: New York, McGraw-Hill Book Company, $752 \mathrm{p}$.

Theis, C.V., 1935, The relation between the lowering of the piezometric surface and the rate and duration of discharge of a well using ground-water storage: American Geophysical Union Transactions, v. 16, p. 519-524.

Tucci, Patrick, and Burkhardt, D.J., 1995, Potentiometric-surface map, 1993, Yucca Mountain and vicinity, Nevada: U.S. Geological Survey WaterResources Investigations Report 95-4149, 15 p. 
Walton, W.C., 1985, Practical aspects of groundwater modeling: Worthington, Ohio, National Water Well Association, $587 \mathrm{p}$.

Whitfield, M.S., Jr., Thordarson, William, and Eshom, E.P.,

1984, Geohydrologic and drill-hole data for test well

USW H-4, Yucca Mountain, Nye County, Nevada:

U.S. Geological Survey Open-File Report 84-449,

$39 \mathrm{p}$. 


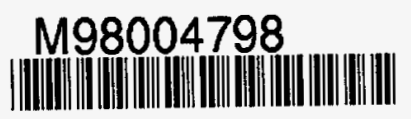

Report Number (14) USGS/W/RIR--97-4166

Publ. Date (11)

Sponsor Code (18) UC Category (19)

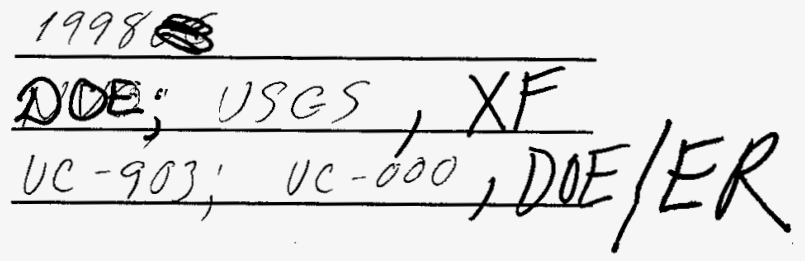

